\title{
Diferenças de gênero em relação a bens: a propriedade fundiária na América Latina ${ }^{1}$
}

CARMEM DIANA DEERE* E MAGDALENA LÉON**

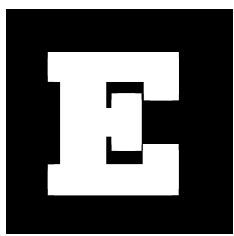

m seu livro pioneiro, A Field of One's Own: Women and Land Rights in South Asia, Agarwal (1994) apresenta os argumentos a favor do direito de posse da terra para as mulheres, em termos de seu bem-estar, sua eficiência, igualdade e empoderamento, e esses argumentos estão começando a encontrar ressonância no pensamento e nas práticas das agências internacionais. Conforme o argumento apresentado pelo Human Development Report do PNUD, em 1997,

A igualdade de gêneros precisa fazer parte da estratégia de cada país para a erradicação da miséria, tanto como um fim quanto como um meio de erradicar outras formas de miséria humana. Isso significa... empoderar as mulheres por meio da garantia de direitos iguais e acesso a terra, crédito e oportunidades de trabalho (UNDP, 1997, p. 7).

\footnotetext{
1 O presente trabalho se baseia em Deere e León (2001a), um estudo de gênero e direitos fundiários envolvendo 12 países na América Latina. É suplementado por dados a respeito de países não incluídos naquele estudo, e pela coleta de outros dados. As autoras agradecem os comentários muito úteis de dois revisores anônimos e a numerosas instituições da América Latina por fornecerem acesso a conjuntos de dados não publicados. Também agradecem às seguintes pessoas por auxílio na pesquisa sobre os conjuntos de dados: Rosaluz Duran, Merrilee Mardon e Tom Masterson da University of Massachusetts e Alison Vasconez de FLACSO-Quito. Este artigo foi originalmente publicado, em inglês, em World Development, Vol. 31, No. 6, p. 925-947, 2003. Sua tradução e publicação neste número de Sociologias foram autorizadas por Elsevier Science Ltda. A tradução foi feita por Hedy Lorraine Hoffmann.
} 
De modo semelhante, o Rural Poverty Report 2001 reconhece que "reduzir barreiras ao controle de propriedades rurais, especialmente da terra, é crucial à política contra a miséria" (IFAD, 2001, p. 85). Como conclui o relatório de pesquisas sobre políticas, Engendering Development, do Banco Mundial (2001, p. 5),

as mulheres continuam a ter, sistematicamente, menos controle sobre uma série de recursos produtivos....Tais disparidades, seja na educação ou em outros recursos produtivos, prejudicam as mulheres em sua capacidade de participar no desenvolvimento e contribuir para níveis de vida mais elevados para as suas famílias.

Pouco se sabe, contudo, sobre a magnitude da diferença entre gêneros relativa à propriedade, em particular com relação à terra. Os censos agrícolas são deficientes neste sentido, pois pressupõem, implicitamente, que o proprietário de um estabelecimento agrícola operado pelo proprietário deve ser o cabeça da família ou seu agricultor principal. Até recentemente, poucos levantamentos de dados sobre famílias agricultoras foram além disso nas suas pesquisas, perguntando quem era(m) o(s) proprietário(s) legal(is) da terra, ou como ela foi adquirida. Como resultado disso, foram realizadas relativamente poucas pesquisas quantitativas sobre os fatores determinantes da propriedade de bens, especificamente sobre os diferentes mecanismos - via família, comunidade, Estado e mercado - através dos quais é adquirida a terra, e se os vários mecanismos são diferenciados por gênero. A maior parte do livro de Agarwal (1994) enfoca as práticas de herança, que é o meio principal através do qual é adquirida a propriedade de terras no Sul da Ásia. Mas, em outras regiões, tais como a América Latina, onde a agricultura capitalista já está bem desenvolvida, o mercado 
pode agora ser tão ou mais importante do que a família, comunidade, e/ou Estado, na aquisição da terra como propriedade privada. Além disso, em alguns países latino americanos, os programas de reforma agrária foram mais amplos do que no Sul da Ásia. Isso faz surgir a questão da importância relativa de diferentes formas de aquisição de terra, na contribuição para a diferença de gênero na propriedade fundiária.

No presente artigo, mostramos que a diferença de gênero quanto à propriedade da terra, na América Latina, é significativa e isso se deve a cinco fatores: preferência dada aos homens na herança; privilégio masculino no casamento; viés masculino tanto nos programas comunitários como em programas estatais de distribuição de terras; e viés de gênero no mercado fundiário. Todavia, homens e mulheres tendem a adquirir terras de maneiras diferentes: a principal forma das mulheres se tornarem proprietárias é por herança, enquanto que o mercado fundiário é um meio de aquisição de terras relativamente mais importante para os homens. Também existem indicações de que a herança da terra, na América Latina tende a tornar-se mais igualitária, assim como os programas estatais de distribuição e fornecimento de escrituras de terras, mas essas tendências favoráveis estão ocorrendo em um contexto global em que a distribuição de terras está se concentrando cada vez mais, e onde as transações no mercado fundiário são cada vez mais importantes.

Na próxima seção discutimos os problemas metodológicos envolvidos na medição da distribuição da propriedade de terras por gênero e apresentamos os dados quantitativos disponíveis para a América Latina. Então voltamo-nos para a questão de como é adquirida a propriedade da terra, e mostramos que o gênero tem importância. As quatro seções seguintes consideram cada uma das principais formas de aquisição de terra via família, comunidade, Estado e mercado - com maiores detalhes, e 
analisam os fatores que contribuem para a desigualdade de gênero na propriedade fundiária. O tamanho médio de uma propriedade agrícola é considerado a seguir, e mostramos que não apenas é mais provável que os homens sejam proprietários, mas que também tendem a ter propriedades maiores do que as proprietárias do sexo feminino. A seção final apresenta um resumo de tendências recentes, e propõe uma agenda de pesquisa derivada dessa revisão.

\section{A distribuição da propriedade fundiária por gênero}

Mesmo após mais de três décadas de esforços pelos estudiosos e outros que trabalham com "Mulheres/Gênero e Desenvolvimento', para dar visibilidade à mulher rural, poucos censos agrícolas latino americanos publicam dados sobre o gênero dos agricultores do seu país. Além do mais, muitos ainda não incluem a variável "sexo" no questionário do censo. Outrossim, nenhum dos censos agrícolas pergunta quem no lar é o proprietário legal e poucos perguntam como foi adquirida a terra. Os pesquisadores, assim como os formuladores de políticas, continuam a pressupor que as unidades agrícolas operadas pelos seus donos são propriedade do chefe de família. Isso é, claramente, uma pressuposição insatisfatória, já que a "propriedade agrícola familiar" poderá ser do marido, ou da esposa, ou pertencer conjuntamente a ambos, ou a um dos seus pais ou a outro parente que pode ou não residir na casa. Além do mais, cada uma das parcelas que constituem a propriedade fundiária de uma família poderá pertencer a pessoas diferentes, e pode ter sido adquirida de forma diferente.

A fim de derivar uma aproximação, grosso modo, da distribuição de terras por gênero a partir de dados atuais do censo, é necessário pressupor que, dadas as normas vigentes relativas a gênero, as mulheres que se de- 
claram como o agricultor principal de uma parcela operada pelo proprietário sejam de fato as proprietárias. Em outras palavras, dada a construção social de gênero, segundo a qual a agricultura é considerada uma ocupação masculina, deve-se pressupor que poucas mulheres se declarem como a agricultora principal (assim respondendo ao questionário do censo), a não ser que sejam de fato as proprietárias e/ou chefes de família, sem nenhum homem adulto residente na casa. ${ }^{2}$

A tabela 1 apresenta os dados do censo disponíveis sobre o sexo do agricultor principal e, quando disponíveis, aqueles das parcelas administradas pelo proprietário. Em primeiro lugar, desde 1960 apenas quatro países latino americanos publicaram dados sobre o sexo dos seus agricultores; o censo agrícola chileno de 1997 incluiu essa variável no questionário do censo, mas não publicou os resultados (INE, 1998). A tendência tem sido de que cada vez mais países incluam a variável sexo no questionário do censo, mas depois não relatem os resultados em publicações do censo, aparentemente por motivo de considerações orçamentárias. Em segundo lugar, dados censitários sobre o número de agricultores principais do sexo feminino, em parcelas operadas pelo proprietário, apenas estão disponíveis para três países. No Chile, na República Dominicana e no Peru, essa proporção é mais alta do que o número total de agricultoras, refletindo uma tendência de que as mulheres tenham menor probabilidade do que os homens de adquirir terra através de arranjos de arrendamento, tais como aluguel ou meação. Os dados censitários disponíveis ilustram a participação medida relativamente baixa das mulheres como agricultores principais, que vai desde $7 \%$ na Guatemala, até $24 \%$ em propriedades agrícolas operadas pelo dono, no Chile. ${ }^{3}$ Essa primeira aproximação à desigualdade de gênero na propriedade fundiária, na América Latina, sugere que ela tem dimensões realmente significativas.

2 Veja Deere e León $(1982,1987)$ sobre o problema geral de subestimar a participação das mulheres nos censos agrícolas na América Latina.

3 A FAO (1997) publicou dados baseados nos censos agrícolas da década de 1980, sobre aquilo que denominam "proprietários de terra por sexo", para sete países caribenhos que não foram incluídos na nossa análise. A proporção de mulheres que são agricultores principais é substancialmente maior nesses países do que na América Latina, variando de $18 \%$ em Guadalupe a $34 \%$ em Granada e $40 \%$ na Guiana Francesa. 
Tabela 1. Sexo dos agricultores principais nos censos agrícolas, vários anos (\%)

\begin{tabular}{|c|c|c|c|}
\hline & Mulheres & Homens & Total \\
\hline Chile $^{\mathrm{a}}$ (1997) & 21.9 & 79.1 & 100 \\
\hline $\begin{array}{l}\text { Propriedades administradas } \\
\text { pelos proprietários }\end{array}$ & 24.3 & 75.7 & 100 \\
\hline República Dominicana $^{\mathrm{b}}(1960)$ & 11.4 & 88.6 & 100 \\
\hline $\begin{array}{l}\text { Propriedades administradas } \\
\text { pelos proprietários }\end{array}$ & 13.7 & 86.3 & 100 \\
\hline Guatemala $^{c}(1979)$ & 6.6 & 93.4 & 100 \\
\hline Paraguai $^{\mathrm{d}}(1991)$ & 9.4 & 90.6 & 100 \\
\hline Peru $^{\mathrm{e}}(1994)$ & 20.3 & 79.7 & 100 \\
\hline $\begin{array}{l}\text { Propriedades administradas } \\
\text { pelos proprietários }\end{array}$ & 20.6 & 79.4 & 100 \\
\hline
\end{tabular}

Notas e fontes:

a Dados não publicados fornecidos às autoras pela Unidade de Desenvolvimento Agrícola, CEPAL, com base em INE (1998).

b República Dominicana (1966: Tabela 7a).

c Guatemala (1985: Tabelas 10 e 11).

d Paraguai (1993: Tabela 10).

e Ministério de Agricultura (1998: Tabela 10).

Outra fonte potencial de dados sobre a distribuição de bens são os levantamentos em grande escala sobre nível de vida (LSMS-Living Standard Measurement Survey), patrocinados pelo Banco Mundial e realizados em uma série de países da América Latina durante a década de 1990. Um indicativo da falta de atenção à questão de propriedade fundiária e sua distribuição por gênero até há pouco tempo é o fato da informação por gênero sobre que membro da família realmente é o dono legal da terra não ter sido obtida na maioria dos países. Como em alguns dos censos agrícolas, é apenas possível deduzir a proporção de mulheres que são os agricultores principais, em propriedades operadas pelo dono, e pressupor que sejam estas as proprietárias das terras. ${ }^{4}$ 
O LSMS Peruano de 2000 foi o primeiro na América Latina a perguntar especificamente se a parcela de terra pertencia à pessoa que estava respondendo ou a outro membro da família, e depois complementar aquela pergunta com a mais importante para nossos fins: se a escritura estava em nome do chefe da família, do cônjuge, do casal, de outro membro da família, ou de outros, e se esses últimos casos eram em co-propriedade. ${ }^{5}$ Conforme se mostra na tabela 2 , a posse conjunta da terra por casais é um fenômeno bastante comum no Peru, sendo 13\% das parcelas de terra de propriedade conjunta do marido e da mulher. Uma proporção adicional de $13 \%$ das parcelas são de propriedade individual das mulheres, e 74\% dos homens. Ao todo, se as parcelas cujo título de propriedade é conjuntamente de um casal são atribuídas a ambos os sexos, as mulheres (individualmente ou em conjunto) são proprietárias de $23 \%$ das parcelas de terra. Outra maneira de medir até que ponto chega a propriedade pelas mulheres é considerando a proporção de famílias nas quais as mulheres têm os direitos sobre a terra, seja individualmente ou em conjunto com o seu parceiro. Esta cifra, 28\%, é consideravelmente mais alta do que a cifra do censo de 1994 quanto à proporção de famílias, 21\%, nas quais as muIheres são os agricultores principais (Tabela 1).

O LSMS de 2000-01 para o Paraguai também procurou saber sobre direitos de propriedade por sexo, mas apenas em termos da unidade agrícola. Esse levantamento revelou que, em $27 \%$ das famílias, o proprietário era mulher; em $70 \%$, homem; e nos $3 \%$ restantes, a terra era ou de propriedade individual de um homem e também de uma mulher, ou de propriedade conjunta do casal. A proporção de famílias nas quais as mulheres têm direitos à terra, 30\%, é substancialmente maior do que a estimativa do censo de 1991, 9\%, da parte de agricultoras (Tabela 1).

O levantamento nicaragüense em 1995 foi baseado numa amostra representativa de famílias rurais; apenas 32\% das 3.015 famílias entrevistadas eram proprietárias de terras, ilustrando a importância numérica dos

5 Um problema no levantamento peruano é o grande número de casos que faltam, a respeito de escrituras de propriedade, afetando $26 \%$ do total de 2.786 parcelas. Isso, em grande parte, reflete a condição ambígua dos direitos fundiários nas comunidades camponesas oficialmente reconhecidas. Enquanto que parcelas adquiridas através da condição de membro de uma comunidade agora são geralmente reconhecidas como propriedade privada, relativamente poucas dessas têm escrituras e registro oficial. Além disso, dados por gênero não foram coletados com relação a parcelas de propriedade de outros membros ou não-membros da família, e esses também foram excluídos da análise. 
agricultores sem terra neste país. Conforme mostrado na tabela 2, daquelas famílias que detinham a posse de terras, em $15.5 \%$ o proprietário era muIher, enquanto que, em $4 \%$, a terra era possuída conjuntamente por um casal; assim, em 19\% das famílias as mulheres detinham o direito à terra. Para o Brasil, os únicos dados nacionais sobre propriedade fundiária por gênero provêm de um levantamento nacional de agricultores comerciais, definidos como aqueles que possuem 50 ha ou mais de terra. Nessa amostra de 36.664 proprietários, $11 \%$ eram mulheres. O questionário do levantamento não permitia a opção dos proprietários relatarem se a sua terra era em propriedade conjunta com os cônjuges, potencialmente subestimando a proporção de mulheres que são legalmente proprietárias.

Os dados disponíveis a respeito de propriedade fundiária por sexo, no México, são para o setor de ejido (que é responsável por aproximadamente metade das terras agrícolas do México), provenientes do atual programa de distribuição de escrituras da terra naquele país. É mais semeIhante a um censo, pois, em 2000, três quartos dos ejidos já tinham completado o programa de escrituração e certificação da terra (Robles, Artís, Salazar \& Muñoz, 2000). Uma característica particular desse programa de titulação da terra era que, segundo as regras para ser membro do ejido, apenas uma pessoa por família, o seu chefe, recebia o título de patrimônio familiar da terra. Conforme mostra a tabela 2 , as mulheres representavam $22 \%$ daqueles que recebiam a escritura. ${ }^{6}$

Esta revisão dos dados disponíveis sobre a propriedade fundiária por gênero para a América Latina sugere os seguintes pontos metodológicos. Primeiro, a medida mais acurada da distribuição da propriedade da terra por gênero é derivada considerando a posse de cada parcela que constitui a propriedade agrícola familiar. Não se deve pressupor que todas as parcelas pertençam ao mesmo proprietário, para não falar de que constituam a propriedade apenas do chefe de família. Em segundo lugar, a fim de medir rigorosamente a distribuição de bens por gênero, é importante levar em

6 Houve diferenças importantes por gênero na forma e quantidade de terras escrituradas. As mulheres constituíam apenas $18 \%$ dos ejidatários, aqueles que previamente tinham direitos fundiários assegurados nos ejidos, e voz e voto na assembléias comunitárias. Eram uma proporção levemente maior, $23 \%$, daqueles que antes apenas tinham direitos fundiários informais (conhecidos como posesionarios), e como resultado do programa de fornecimento de escrituras da terras também se tornaram proprietárias individuais. As mulheres representavam uma proporção muito maior daqueles terrenos de casas urbanas escrituradas nos ejidos (os avecindados), sendo quase um terço dessa categoria de beneficiários (Robles et al., 2000, p. 20-21). 
conta o regime conjugal, já que são esses que definem os direitos de propriedade das mulheres casadas. O regime conjugal legal na maioria dos países latino americanos é o regime de comunhão parcial de bens (gananciales), através do qual quaisquer bens adquiridos pelo casal durante o casamento, a partir de salários, aluguéis e lucros, constituem a propriedade comum do casal. ${ }^{7}$ Segundo esse regime, bens que são adquiridos antes do casamento constituem a propriedade individual de cada cônjuge. Ao não se levar em conta a propriedade comum (como no caso do levantamento brasileiro relatado acima), provavelmente se subestima o grau de propriedade fundiária da mulher.

Tabela 2. Distribuição de proprietários de terra por Gênero, vários anos (\%)

\begin{tabular}{|l|c|c|c|c|c|}
\hline & Mulheres & Homens & Casal & Total & \\
\hline Brasil $^{\mathrm{a}}(2000)$ & 11.0 & 89.0 & - & 100 & $\mathrm{n}=39,904$ \\
\hline México $^{\mathrm{b}}(2002)$ & 22.4 & 77.6 & - & 100 & $\mathrm{n}=2.9 \mathrm{~m}$. \\
\hline Nicaragua $^{\mathrm{c}}(1995)$ & 15.5 & 80.9 & 3.6 & 100 & $\mathrm{n}=839$ \\
\hline Paraguai $^{\mathrm{d}}(2001)$ & 27.0 & 69.6 & 3.2 & 100 & $\mathrm{n}=1,694$ \\
\hline Peru $^{\mathrm{e}}(2000)$ & 12.7 & 74.4 & 12.8 & 100 & $\mathrm{n}=1,923$ \\
\hline
\end{tabular}

Notas e fontes:

${ }^{a}$ Dados referentes a propriedades maiores que 50 hectares, extraído do Censo Comunitário Rural 2000, Confederação Nacional Agrária, Brasília.

${ }^{b}$ Referente apenas a ejidos, inclui ejidatarios, posesionarios e avecindados (Beyer, 2002, p. 2).

c Excluídos membros de cooperativas de produção, pesquisa de domicílios rurais FIDEG (Renzi and Agurto, 1997, p. 74).

${ }^{d}$ Dados referentes a famílias com títulos de propriedade da terra, derivados da pesquisa LSMS, MECOVI (Mejoramiento de las Condiciones de Vida), 2002-2001, Ministerio de Agricultura y Ganaderia, Asunción.

e Dados baseados na distribuição de propriedade sobre parcelas de terras tituladas; excluem os que não são membros da família. Derivados da pesquisa LSMS, ENNVI (Encuesta Nacional de Niveles de Vida), 2000, Instituto Cuanto, Lima.

7 As principais exceções na América Latina são a Costa Rica, Honduras e Nicarágua, onde o regime matrimonial legal é a separação total da propriedade, e El Salvador, onde é regime de propriedade comum plena (onde os bens adquiridos antes do casamento ou a herança após o casamento também são reunidos em um só). Por ocasião do casamento, na maioria dos países, pode-se escolher entre duas ou três opções, embora a maioria dos casais tenda a casar sob o regime legal (Deere \& León, 2001a, Cap. 2). 
Em terceiro lugar, é provável que, na América Latina, um número maior de mulheres possua terras do que a proporção de mulheres que são agricultoras principais nas suas famílias, conforme demonstrado nos casos do Peru e do Paraguai, devido à construção social dos papéis de gênero. Os dados disponíveis sobre a propriedade fundiária, apesar disso, ilustram o nosso ponto principal: a distribuição de propriedade fundiária por gênero, na América Latina, é extremamente desigual, sendo que as mulheres raramente representam mais de um quarto dos proprietários. Além do mais, a diferença de gênero na propriedade fundiária também varia consideravelmente em toda a América Latina, e provavelmente é menos aguda nos países andinos e no México do que em outras regiões, refletindo variáveis tais como diferenças de regime conjugal, normas e práticas relativas à herança, políticas estatais de distribuição da terra, e o grau de desenvolvimento do mercado fundiário, fatores a serem investigados abaixo.

\section{Diferenças de gênero na forma de aquisição de terras}

Até recentemente, deu-se pouca atenção às diferentes maneiras pelas quais é adquirida a propriedade da terra e como diferem por gênero (Agarwal, 1995; de Janvry, Platteau, Gordillo \& Sadoulet, 2001a). Conforme observado acima, os meios principais de aquisição de propriedade fundiária são através da família por herança, da comunidade seja por herança ou por redistribuição de terras, do Estado através de programas de distribuição de terras ou de recebimento de escrituras de terras públicas e compras no mercado. Na América Latina, os homens são favorecidos em todas as formas de aquisição de terras. Conforme mostra a tabela 3, todavia, para seis países, há notáveis diferenças por gênero na maneira pela qual é adquirida a terra (como um todo, a distribuição por gênero e forma de aquisição de terras foi estatisticamente significativa ao nível de confiança de $99 \%$ ). 
Tabela 3. Forma de aquisição da terra por gênero (\%)

\begin{tabular}{|c|c|c|c|c|c|c|c|}
\hline & Herança & Comunidade & Estado & Mercado & Outra & Total & \\
\hline Brasil $^{a} *$ & & & & & & & \\
\hline Mulheres & 54.2 & - & 0.6 & 37.4 & 7.8 & 100 & $\mathrm{n}=4,345$ \\
\hline Homens & 22.0 & - & 1.0 & 73.1 & 3.9 & 100 & $\mathrm{n}=34,593$ \\
\hline Chile $^{b *}$ & & & & & & & \\
\hline Mulheres & 84.1 & - & 1.9 & 8.1 & 5.9 & 100 & $n=271$ \\
\hline Homens & 65.4 & - & 2.7 & 25.1 & 6.8 & 100 & $\mathrm{n}=411$ \\
\hline Equador $^{\mathrm{c}} *$ & & & & & & & \\
\hline Mulheres & 42.5 & - & 5.0 & 44.9 & 7.6 & 100 & $n=497$ \\
\hline Homens & 34.5 & - & 6.5 & 43.3 & 15.6 & 100 & $\mathrm{n}=1,593$ \\
\hline México $^{\mathrm{d}} *$ & & & & & & & \\
\hline Mulheres & 81.1 & 1.8 & 5.3 & 8.1 & 3.7 & 100 & $\mathrm{n}=512$ \\
\hline Homens & 44.7 & 14.8 & 19.6 & 12.0 & 8.9 & 100 & $\mathrm{n}=2,547$ \\
\hline Nicarágua $^{\mathrm{e}} *$ & & & & & & & \\
\hline Mulheres & 57.0 & - & 10.0 & 33.0 & - & 100 & $\mathrm{n}=125$ \\
\hline Homens & 32.0 & - & 16.0 & 52.0 & - & 100 & $\mathrm{n}=656$ \\
\hline Peru $^{f *}$ & & & & & & & \\
\hline Mulheres & 75.2 & 1.9 & 5.2 & 16.4 & 1.3 & 100 & $\mathrm{n}=310$ \\
\hline Homens & 48.7 & 6.3 & 12.4 & 26.6 & 6.0 & 100 & $\mathrm{n}=1,512$ \\
\hline Casais & 37.3 & 1.6 & 7.7 & 52.6 & 0.8 & 100 & $\mathrm{n}=247$ \\
\hline
\end{tabular}

Notas e Fontes:

* A distribuição por gênero é estatisticamente significativa ao nível de confiança de $99 \%$.

a Dados extraídos do Censo Comunitário Rural, 2000, op. cit.. A categoria 'outras' inclui doações de particulares.

${ }^{b}$ Referente apenas a propriedades maiores de $5000 \mathrm{~m}^{2}$; dados extraídos da pesquisa Evaluación del Impacto del Programa de Saneamiento y Regularización de la Pequeña Propiedad Rural, 1997, fornecidos pelo Ministerio de Bienes Nacionales, Santiago, July 1997. A categoria 'outros' inclui doações imperfeitas por particulares e outras respostas.

' Dados derivados da pesquisa LSMS, Encuesta de Condiciones de Vida 1999, INEC, Quito; baseados no total de parcelas de terra adquiridas por 1586 indivíduos, assumindo-se que o agricultor principal seja o proprietário. A categoria 'outros' inclui terra em usufruto, que é tratada como propriedade particular.

${ }^{d}$ Dados baseados na amostra nacional representativa de ejidatarios e posesionarios; baseados no total de parcelas tituladas a 1576 indivíduos (Procuraduría Agraria, 1998: Tabela 1). A categoria 'outros' inclui propriedades distribuídas com base em ações judiciais. e Referentes apenas a proprietários individuais (Renzi and Agurto,1997, p. 75).

'Dados derivados de ENNVI, 2000. A categoria 'outros' inclui parcelas mantidas em co-propriedade com membros ou não membros da família, sem indicação de sexo.

Embora, em termos absolutos, os homens sejam favorecidos por práticas relativas à herança, a herança em si é um mecanismo relativamente mais importante de acesso à propriedade da terra para as mulheres. Conforme mostra a tabela 3, em cinco países - Brasil, Chile, ${ }^{8}$ México, Nicará-

8 Os dados chilenos são tirados de um levantamento de amostragem dos beneficiários do programa recente de escrituração de terras realizado naquele país, entre os pequenos agricultores. Esses dados não foram incluídos na Tabela 2, pois o levantamento não era uma amostra nacionalmente representativa dos proprietários chilenos. Além disso, como um dos objetivos do programa de escrituração era de dar atenção prioritária à mulheres chefes de família, o levantamento pode ter sobre-representado as mulheres. As mulheres constituíam $39, .8 \%$ das unidades agrícolas escrituradas e $43,4 \%$ dos terrenos de terras com escritura (menos de $5.000 \mathrm{~m}^{2}$ ), para um total de $42,8 \%$ dos beneficiários. Esta última cifra é aproximadamente o dobro da proporção de agricultoras relatada na Tabela I. Veja Deere e León (2001a, Cap. 9). 
gua e Peru - a herança é o meio principal de acesso a terras para as mulheres, e mais de metade das proprietárias adquirem suas terras por herança. O Equador é o único caso no qual o mercado foi uma fonte ligeiramente mais importante de aquisição de terras para as mulheres do que a herança, mas, ainda assim, está de acordo com o padrão em que a herança é uma fonte de aquisição de terras relativamente mais importante para as mulheres do que para os homens. ${ }^{9}$

Em todos os países (com exceção do Equador), o mercado fundiário seguiu-se à herança quanto a sua importância relativa como fonte de aquisição de terras por mulheres, mas foi um meio importante (compreendendo pelo menos um terço dos casos) apenas no Brasil e na Nicarágua. Uma proporção relativamente pequena de mulheres adquiriu sua terra por meio de programas de reforma agrária ou assentamento, o número maior sendo na Nicarágua, onde $10 \%$ das proprietárias adquiriram suas terras dessa maneira. Nos dois países, o México e o Peru, onde uma parte significativa das terras é de propriedade de comunidades camponesas e indígenas, e onde na última década esta se tornou uma fonte importante para a aquisição de propriedades privadas em termos de terra, a proporção de mulheres que adquiriram terras por esse meio foi insignificante.

A aquisição de terras pelos homens, segundo a fonte, apresenta maior variação de um país para outro do que a das mulheres. No Brasil, Equador e Nicarágua, o principal meio através do qual os homens adquirem terras é pelo mercado. ${ }^{10}$ Entretanto, é no Brasil e na Nicarágua que as diferenças de gênero no padrão de aquisição de terras são mais evidentes. No Chile, México e Peru, a herança é o meio principal pelo qual tanto

9 Os dados chilenos são tirados de um levantamento de amostragem dos beneficiários do programa recente de escrituração de terras realizado naquele país, entre os pequenos agricultores. Esses dados não foram incluídos na Tabela 2, pois o levantamento não era uma amostra nacionalmente representativa dos proprietários $\mathrm{C}$

as parcelas de terra, mas não perguntou quem, na família, era o proprietário legal. Atribuímos a propriedade da terra ao agricultor principal (sendo que as mulheres constituem 26\% deles), mas esta suposição é claramente pouco satisfatória, conforme discutido na seção prévia. Incluímos os levantamentos do Equador e do Chile na Tabela 3, apenas por que é tão difícil obter dados sobre a forma de aquisição de terras por gênero.

10 Deve ser levado em conta, porém, que as compras de mercado talvez não independam de práticas de herança, como por exemplo, quando um dos irmãos compra as partes de terra herdadas pelos outros irmãos, ou usa outros bens herdados para comprar terras. 
homens como mulheres adquirem terras. Enquanto que no Chile e no Peru o mercado segue-se à herança em importância, no México a aquisição de terras por meio de distribuição pelo Estado ou pela comunidade é gigantesca ao lado do mercado. Esse último resultado não é surpreendente, já que, até a reforma de 1992, a venda de terras nos ejidos era tecnicamente ilícita. O que se destaca no México, bem como no Peru, é como a aquisição de terras via Estado ou comunidade tem tido um grande viés em relação a gênero. Cada um dos principais mecanismos de aquisição da propriedade fundiária é considerado com maiores detalhes abaixo.

\section{A família}

Estabelecemos, acima, que a herança foi o meio principal de aquisição de terras pelas mulheres na maioria dos países, embora, em termos absolutos, os homens sejam favorecidos na herança comparativamente às mulheres. Aqui analisamos mais detalhadamente os mecanismos de discriminação contra mulheres dentro das famílias, distinguindo entre a normas de herança para filhos e para cônjuges, e consideramos os direitos de propriedade das esposas, de modo mais geral. Também revisamos tendências recentes nas práticas de herança que sugerem que a herança de terras na América Latina possa estar se tornando mais eqüitativa do ponto de vista de gênero.

a) Herança pelos filhos

A América Latina tem uma tradição jurídica relativamente favorável comparada com outras regiões do mundo, ${ }^{11}$ pois as mulheres podiam herdar terras de acordo com as normas das principais civilizações pré-colombianas, bem como durante o período colonial. Embora os dados sobre o período antes da Conquista sejam escassos, uma série de civilizações pré- 
colombianas parece ter tido normas de herança relativamente igualitárias em termos de gênero, especificamente sistemas de herança paralelos ou bilaterais (Silverblatt, 1989; Socolow, 2000). Nos sistemas de herança paralelos, os filhos herdam através da linha masculina, e as filhas através da linha feminina. A herança bilateral é caracterizada pelo fato de filhos de ambos os sexos herdarem de ambos os pais; assim, pressupõe que as muIheres sejam donas de e herdem propriedades que elas podem transmitir aos seus filhos.

Segundo a tradição jurídica luso-hispânica, a herança também era bilateral, todos os filhos, de não importa qual sexo herdavam partes aproximadamente iguais do espólio de cada um dos pais. Na América Colonial hispânica, a liberdade testamentária era limitada a apenas um quinto do espólio de um dos pais, embora um terço adicional, as "benfeitorias" ou mejoras, podia ser deixado em testamento a apenas um, ou a vários dos descendentes legítimos. Assim, o viés de gênero que podia ser introduzido através de testamentos era legalmente limitado. Se um dos pais falecesse sem deixar testamento, o espólio inteiro era dividido em partes iguais entre todos os filhos legítimos, sem levar em conta o sexo (Couturier, 1985; Socolow, 2000).

Dadas as normas de herança relativamente igualitárias quanto aos filhos, por que a herança de terras, na América Latina contemporânea, apresenta um viés tão grande a favor dos homens? Um motivo tem a ver com os papéis de gênero. Muitas regiões da América Latina são caracterizadas por uma divisão de trabalho por gênero, que define a agricultura como uma ocupação masculina; as mulheres são vistas, sobretudo, como donas de casa, não importa qual seja sua contribuição à agricultura familiar. O trabalho agrícola das mulheres tende a ser invisível, considerado simplesmente como "ajuda" ao marido, ou como secundário ao papel principal das mulheres no fornecimento de trabalho doméstico. Tanto a falta de trabalho das mulheres na agricultura como a invisibilidade e falta de re- 
conhecimento social desse trabalho podem servir como mecanismos de exclusão das mulheres do direito à terra. Essa diferenciação por gênero é reforçada onde a herança da terra é vista como um direito "merecido", segundo o princípio de que a terra deve pertencer àqueles que trabalham ou que a merecem (pelo trabalho) (Carneiro, 2001; Woortman, 1995).

A divisão prevalente do trabalho por gênero é, então, muitas vezes espelhada na composição da herança, sendo que filhos e filhas herdam coisas diferentes. As filhas poderão herdar os animais, utensílios domésticos, dinheiro ou uma casa, enquanto que a terra é concentrada na linha masculina. Enquanto tanto filhos como filhas, assim, herdam dos seus pais, as partes da herança nem sempre são de igual valor. Relativamente poucas pesquisas foram realizadas sobre o valor das partes de herança diferenciadas por gênero, mas as evidências disponíveis sugerem que, geralmente, é desfavorável às filhas (Woortmann, 1995). ${ }^{12}$ Esse é particularmente o caso quando se leva em conta que a terra tem valor não apenas econômico, mas também simbólico, dentro das comunidades camponesas (Carneiro, 2001).

A desigualdade de gênero na herança de terras, em comunidades camponesas da América Latina, também foi associada com patrilinearidade, patri ou virilocalidade, exogamia, e o que foi chamado de "lógica da reprodução do lar camponês". A patrilocalidade refere-se à residência de um casal jovem no lar paterno do noivo, enquanto que virilocalidade refere-se à residência em terras associadas com a linha paterna. Ambos se associam com a exogamia, onde as mulheres casam fora de sua comunidade de origem. Privar filhas de direitos de herança da terra justifica-se nesses sistemas, pois as mulheres saem da comunidade, e "não podem levar as terras consigo"; além disso, espera-se que a família do marido lhes forneça terras (Córdova Plaza, 2000). ${ }^{13}$

\footnotetext{
12 Sugeriu-se, para outras regiões do mundo, que uma diferenciação por gênero, na composição da herança, seria favorável às mulheres, como, por exemplo, quando os pais compensam a herança de terras pelos filhos investindo na educação das filhas. Veja Estudillo, Quisumbing e Otsuka (2001) sobre as Filipinas, e Quisumbing e Otsuka (2001) sobre Sumatra. Essa proposta ainda deverá ser investigada no caso latino americano, talvez porque, até há pouco tempo, as taxas de escolaridade e, assim, de investimentos em educação, em grande parte favoreciam os filhos em lugar das filhas.

13 O local de residência após o casamento é um dos fatores mais fortes associados com diferentes sistemas de herança, através das culturas. Por exemplo, no estudo exaustivo feito por Agarwal (1994, p. 140-144) sobre sistemas de herança no Sul da Ásia, ela constatou que os direitos de herança das mulheres, em sistemas matrilineares e bilaterais, estavam estreitamente associados com o fato das mulheres casarem e viverem nas suas aldeias natais.
} 
A lógica da reprodução da família camponesa foi às vezes invocada para justificar a preferência masculina e o costume de priorizar apenas um filho na herança. Onde o acesso à terra é limitado, a herança da terra é uma condição fundamental de reprodução da família camponesa, pois o acesso à terra é o que garante a continuidade da unidade de produção e reprodução entre gerações. Nessas circunstâncias, a continuidade do patrimônio familiar é melhor garantida através da restrição da divisão de terra via sistemas de herança que priorizem o filho mais velho ou mais jovem, e deserdem as filhas do acesso à terra. Privilegiar um filho nos direitos de herança da terra (particularmente o mais jovem) também serve para garantir a seguridade dos pais na velhice, já que o herdeiro único é obrigado a permanecer em casa, cuidando dos pais idosos e lavrando a terra, na expectativa da herança (Carneiro, de Freitas \& Guedes, 1998).

A medida do viés que favorece filhos difere através da América Latina, variando não apenas por país, mas também por sub-regiões e comunidades. Em Deere e León (2001c, Cap. 8), resumimos o material etnográfico para os seis países da América Latina que têm a mais extensa literatura, e estabelecemos dois padrões amplos com relação à herança da terra pelos filhos: um, onde predomina a herança bilateral, e a herança de terras é relativamente igualitária com relação a gênero; o outro, onde a herança de terras tem um forte viés favorecendo os homens. A herança bilateral é mais comum nos países andinos com grandes populações indígenas: Equador e Peru, em particular, e em escala menor na Bolívia. Os países caracterizados por um forte viés masculino na herança de terras eram bastante diferentes etnicamente - México, Chile e Brasil - mas predominantemente mestiços. Isso leva à questão de por que a diferença de bens entre os gêneros, para terras, nas Tabelas 1 e 2 parece menos aguda no México e no Chile do que em outros países. A fim de responder a esta pergunta, devemos voltar-nos para as normas que governam a herança de terras por viúvas. 
b) Casamento e os direitos de propriedade das esposas

Segundo a tradição jurídica luso-hispânica, os cônjuges geralmente não herdavam um do outro, a não ser que o falecido não deixasse descendentes vivos, ascendentes, ou parentes colaterais; podiam, contudo, ser os beneficiários de uma parte do espólio (o quinto) que poderia ser dado livremente em testamento. As mulheres casadas, apesar disso, tinham direitos de propriedade relativamente fortes quanto a propriedades adquiridas durante o casamento. Segundo o regime conjugal de comunhão parcial de bens (gananciales, o regime legal na América Espanhola colonial, e na maioria dos países hoje), em caso de separação, divórcio ou morte, a propriedade comum da união é dividida em partes iguais entre os cônjuges. $\mathrm{O}$ espólio de cada cônjuge é assim constituído por metade da propriedade comum, além de qualquer propriedade de posse individual adquirida antes do casamento (como por exemplo o dote), ou por herança antes ou depois do casamento. ${ }^{14}$

Embora as mulheres casadas tivessem direitos de propriedade relativamente fortes (em particular quando comparadas com mulheres anglosaxônicas nesse período), esses direitos eram limitados na prática, pelo fato que, até o fim do século XX, os maridos eram o único chefe legal da família. ${ }^{15}$ Apenas os maridos representavam a família e gerenciavam os seus bens, inclusive a propriedade individual de suas esposas. Embora os maridos não pudessem alienar a propriedade de suas esposas sem a sua permissão, nenhuma restrição desse tipo se aplicava à propriedade comum (aquela que era adquirida conjuntamente durante o casamento, a partir de salários, aluguéis ou lucros), a não ser que a propriedade estivesse registrada em nome do marido e da mulher. A escritura conjunta dos bens, porém, era uma prática rara, pois os maridos representavam a família. Isso favorecia o acúmulo dos bens nas mãos dos homens, e permitia que os maridos dispusessem da propriedade comum como quisessem, venden-

14 No Brasil colonial, o regime jurídico de propriedade conjugal era de comunhão total de bens, todas as propriedades (inclusive heranças) sendo reunidas e divididas em metades iguais quando da dissolução da união. Desde 1977, o regime de comunhão parcial de bens é o regime legal (default) (Deere \& León, 2001a).

15 Veja Deere e León (2001a, Cap. 2) sobre o processo através do qual as famílias com chefia dupla se tornaram a norma, na maioria dos países latino americanos, no último quarto do século XX. 
do-a, por exemplo, antes da separação ou do divórcio, ou distribuindo-a entre os filhos do sexo masculino antes de sua morte. O privilégio masculino no casamento - como chefes legais da família - assim, contribuiu diretamente para a diferença de gênero em relação aos bens, em termos da distribuição efetiva da propriedade dos bens e indiretamente, através do viés masculino, nas práticas de herança.

Após a independência houve três inovações principais nos regimes de herança: alguns países melhoraram os direitos de herança dos cônjuges, incluindo-os entre os herdeiros necessários, e colocando-os na primeira linha de herança, juntamente com os filhos; ${ }^{16}$ outros adotaram medidas para proteger os viúvos e viúvas contra serem deixados em estado de carência; ${ }^{17}$ finalmente, no final do século XIX, e no início do século XX, o México e os países da América Central adotaram a liberdade testamentária completa. ${ }^{18}$ A liberdade testamentária aumentou o poder de barganha e a autoridade dos pais sobre os filhos, pois esses últimos podiam ser destituídos de qualquer herança se desagradassem a seus pais. Também introduziu uma nova possibilidade de aumentar a desigualdade de gênero na propriedade de bens, pois os pais, por exemplo, agora tinham liberdade para favorecer os filhos em relação às filhas, quanto à herança de terras. ${ }^{19}$ Mas a liberdade testamentária também podia melhorar a situação de algu-

16 Veja Deere e León (2003) sobre as mudanças introduzidas nos direitos de propriedade da mulher, nos códigos civis do século XIX. Bolívia, Argentina e Venezuela foram os primeiros países a darem direitos de herança sobre o espólio do cônjuge falecido a viúvas e viúvos, embora, nos últimos dois países, viúva/viúvos tenham sido excluídos de herdar uma parte dos gananciales. Peru, discutido abaixo, adotou plenos direitos de herança para viúvos/viúvas, em 1984.

17 Na maioria dos países andinos, isso assumiu a forma de "porção conjugal" (porción conyugal), que dependia do valor relativo dos espólios individuais de marido e mulher. Se esses fossem muito desiguais, e o cônjuge sobrevivente pudesse comprovar necessidade econômica, a viúva/viúvo poderia herdar uma parte igual àquela de um filho, mas geralmente não mais de $24 \%$ do espólio. Conforme discutimos em Deere e León (2001a, 2001c), enquanto que a porção conjugal dava certa proteção a viúvas pobres, não era destinada a assegurar que permanecessem no controle da propriedade agrícola ou empresa da família, ou sequer da casa familiar, isto é, a proporcionar-Ihes autonomia econômica.

18 O Brasil acompanhou, em parte, esta última tendência. Em 1907, a liberdade testamentária foi aumentada de um terço para $50 \%$ de um espólio. Nazarri $(1995$, p. 801) discute que a parte que podia ser deixada livremente em testamento foi aumentada a fim de incentivar a maior circulação e acúmulo de capital, um fator que também incentiva o estabelecimento de liberdade testamentária plena ou quase plena, em outros países. Sobre a adoção de liberdade testamentária plena pelo México, veja Arrom (1985, p. 313-315).

19 A potencial desigualdade de gêneros nas partes da herança foi aumentada pelo fato de que, nos códigos civis do século XIX, os pais abastados não tinham mais a obrigação legal de fornecer um dote às suas filhas, o que geralmente era tratado como um adiantamento sobre a sua futura herança. Além disso, no decorrer daquele século, desapareceu gradativamente a prática do dote. Veja Arrom (1985) e Nazarri (1995). 
mas mulheres, em especial as viúvas, já que os maridos agora podiam deixar-Ihes todo o seu espólio em testamento. Essa reforma, assim, criou a possibilidade das viúvas manterem o controle majoritário das terras e empresas da família, e exercerem um poder de barganha consideravelmente maior sobre os seus filhos. Mas o incremento da posse e controle das muIheres sobre a propriedade, dessa maneira, dependia totalmente da boa vontade dos seus maridos.

Não foram realizadas muitas pesquisas sobre herança das esposas, muito menos sobre a herança de terras, de modo que é difícil analisar o impacto de diferentes regimes jurídicos de herança para cônjuges, em relação à diferença de gênero quanto a bens, em termos de terras. Além disso, os quatro países caracterizados por uma proporção relativamente grande de proprietárias, nas tabelas 1 e 2 (Chile, México, Paraguai e Peru), têm diferentes regimes de herança. Apenas no Peru os direitos legais das viúvas são particularmente favorecidos, pois estão incluídas entre os herdeiros necessários, em ordem prioritária. O México é o único desses países com total liberdade testamentária. Como a herança de terras pelos filhos no México, segundo se relata, é particularmente enviesada a favor dos filhos homens (Gonzáles, 1992), seria tentador concluir que a liberdade testamentária deve favorecer as viúvas. Em vez disso, a proporção relativamente elevada de proprietárias, atualmente, deve-se, mais provavelmente, às leis especiais de herança no setor do ejido, que continha várias disposições favoráveis às viúvas.

No regime de ejido (estabelecido em 1920), as parcelas de terra eram indivisíveis e, assim, os direitos à terra apenas poderiam ser transmitidos a uma única pessoa. Mas, desde 1934, se um ejidatario morresse sem testamento, o cônjuge (ou desde 1940, se aplicável, o companheiro permanente) herdava automaticamente o patrimônio fundiário da família (Baitenmann, 1997). Durante 1971-1992 também foi imposta uma restrição sobre a liberdade testamentária completa dentro do regime de ejido, limitando a transmissão de direitos à terra ao cônjuge ou companheiro, ou 
a um só filho. Embora as normas jurídicas, assim, se tenham tornado mais favoráveis às viúvas, os estudos de caso enfatizam quão difícil era mudar as práticas tradicionais de herança que favoreciam os filhos homens em relação às viúvas. A pesquisa de Brunt (1992, p. 82-99), em Guadalajara, demonstra como os direitos fundiários das mulheres muitas vezes são contestados por parentes do sexo masculino. Além disso, quando enfrentam oposição, as mulheres têm dificuldade em defender seus direitos à terra com sucesso, pois precisam convencer os que detêm o poder da legitimidade de suas reivindicações. Isso significa usar os argumentos certos - tais como não exigir o direito à terra para si mesmas, como mulheres, mas em vez disso, em nome dos seus filhos como futuros chefes de família, dominando e manipulando os relacionamentos patrão-cliente da mesma maneira que os homens.

Apesar disso, a tendência no sentido de que a herança favoreça cada vez mais as mulheres é apoiada por dados de um levantamento representativo nacional de ejidatarias. A grande maioria delas herdou seus direitos fundiários: dessas, 50,7\% herdaram direitos à terra do seu marido; 25,4\% do seu pai; $11,4 \%$ da sua mãe; $11,8 \%$ de outros membros da família, e 0,5\% de pessoas que não eram membros da família (Robles et al., 2000, p. 37). Apesar disso, é impossível entender, a partir desses dados, se as muIheres que herdaram terra dos seus maridos o fizeram como resultado do seu testamento (o que seria indicativo de uma mudança nas preferências a favor das esposas), ou como resultado dele ter morrido sem deixar testamento. $^{20}$

Evidências mais fortes de uma mudança que favorece as esposas com direitos fundiários sobre os ejidos são apresentadas na tabela 4, com base em 14099 testamentos escritos, registrados entre 1993 e 1995. O programa de escrituração fundiária exigia que os proprietários fizessem um testamento; além disso, pelas mudanças introduzidas no código agrário do Mé-

20 Como o herdeiro, por default, é a esposa ou companheira, o fato de não fazer um testamento pode, também, ser uma decisão consciente, favorecendo o cônjuge, uma opção que poupa os custos envolvidos em fazer um testamento e, algo que poderá reduzir o atrito entre os filhos. 
xico em 1992, a liberdade testamentária foi mais uma vez estendida ao regime de ejido, embora a restrição sobre a indivisibilidade das parcelas de ejido continue em vigor. Pode-se ver que os testamentos estavam mais ou menos igualmente divididos entre aqueles que atualmente favorecem sua esposa ou companheira como herdeira única, e aqueles que favoreciam um filho do sexo masculino. A tendência no sentido de favorecer as esposas em lugar de um filho provavelmente esteja relacionada ao aumento da expectativa de vida no decorrer do século XX, e à diferença crescente entre os gêneros, quanto à expectativa de vida, pois as mulheres vivem aproximadamente cinco anos mais do que os homens (Valdes \& Gomariz, 1995, p. 115). Essa tendência poderá ser uma compensação pela deterioração dos sistemas tradicionais de suporte dos idosos. Também se discute que, em algumas regiões do México, a tendência de favorecer as esposas no caso de direitos fundiários está associada com o reconhecimento crescente do papel das mulheres na agricultura (Córdova Plaza, 2000).

Tabela 4. Herdeiros de ejidatários registrados, 1993-95, Mexico (\%)

\begin{tabular}{|l|l|}
\hline Esposas/Companheiras & 38.5 \\
Filhas & 8.8 \\
Netas & 0.4 \\
\hline Sub-total, mulheres & 47.7 \\
\hline Filhos & 38.8 \\
Netos & 2.5 \\
\hline Sub-total, homens & 41.3 \\
\hline Outros parentes & 10.0 \\
\hline Não-parentes & 1.0 \\
\hline & $100.0(\mathrm{n}=14,099)$ \\
\hline
\end{tabular}




\section{c) Tendências recentes nas práticas de herança}

O que nos interessava mais no material etnográfico eram esses padrões de mudança no tempo e as condições sob as quais a herança de terra torna-se mais eqüitativa. Na literatura, encontramos os seguintes fatores causalmente associados com uma tendência para a herança de terra mais igualitária em termos de gênero: (i) maior alfabetização, inclusive em termos de conhecimentos jurídicos, de modo que havia maior conhecimento de leis nacionais que favoreciam a igualdade de partes de herança entre os filhos e/ou os direitos das viúvas; (ii) um movimento em prol de práticas de partilha da herança, que também está associada com o tamanho menor das famílias; (iii) maior migração pelos filhos de ambos os sexos, de modo que há menos herdeiros em potencial interessados em continuar nas atividades agrícolas; e (iv) cada vez maior escassez de terras e/ou um declínio na agricultura camponesa, associada com o fato das famílias se basearem cada vez menos na agricultura como a sua principal atividade geradora de renda.

Os dados sobre o México, discutidos acima, proporcionam as evidências mais claras da tendência, no decorrer do século XX, para que as viúvas sejam favorecidas pela herança da propriedade agrícola familiar, uma tendência apoiada pelas normas jurídicas sobre herança nos ejidos, e o conhecimento cada vez maior sobre questões jurídicas. Também existe alguma evidência de que as mães, muito mais do que os pais, tendem a incluir as filhas como herdeiras, e assim, o fato das viúvas herdarem a terra pode apoiar uma tendência para uma cultura de igualdade de gêneros na herança. Nos testamentos relatados na Tabela 4, embora tanto ejidatarios do sexo masculino como feminino tenham preferido um filho como herdeiro único, $19 \%$ das mulheres designaram uma filha como herdeira única, comparado com apenas 5\% dos homens (Valenzuela \& Robles, 1996, p. 52). 
O levantamento mexicano sobre ejidatarias também revelou que havia maior probabilidade das mulheres terem herdado terra quando eram seguidas práticas de partilha da herança, uma prática que era tecnicamente ilegal nos ejidos. Das 402 ejidatárias que herdaram a sua parcela de terra, quase um quarto o fez como resultado de partilha da herança (Robles et al. 2000, p. 41). Mais de um terço das ejidatárias planejaram deixar sua terra em testamento a mais de um herdeiro. As filhas representavam mais de um terço dos beneficiários propostos nesses casos, comparado com apenas $20 \%$ quando se planejava ter apenas um herdeiro (Robles et al, 2000, p. 67-69), sugerindo que a partilha da herança favorece a igualdade de gênero. Outras pesquisas no México ligaram a tendência para a partilha da herança ao tamanho menor da família, migração cada vez maior tanto de filhos como de filhas, e a regiões onde a agricultura não é mais a atividade principal da família (Gonzáles, 1992, p. 414-420).

Um exemplo do Peru ilustra como a relativa escassez de terras e o fato das famílias camponesas se basearem cada vez mais em atividades múltiplas de geração de renda podem romper a lógica da reprodução de famílias camponesas, ou a necessidade de concentrar a terra em filhos homens ou em apenas um deles. Segundo de la Cadena (1995), até e inclusive as primeiras décadas do século XX, o costume na comunidade Quéchua, no departamento de Cuzco que ela pesquisou, era que o filho mais velho herdasse a maior parte da terra da família. Mas o sistema de herança era tecnicamente bilateral. Enquanto que o filho mais velho herdava até $80 \%$ das propriedades da família, e um segundo filho poderia herdar mais 10 a $15 \%$ da terra, todos os outros filhos e filhas herdariam a terra restante e a dividiriam entre si. À medida que se tornou mais extremada a fragmentação das terras, e mais freqüente a participação em múltiplas atividades geradoras de renda, surgiu um padrão mais igualitário em termos de gênero, com todos os filhos, independente de gênero, herdando partes aproximadamente iguais de terra. De la Cadena afirma que a propriedade da terra tornou-se cada vez mais feminina, à medida que a terra perdia o seu valor prévio como fonte de renda e de poder dentro da comunidade. 
Há relatórios de todas as terras altas do Peru, Bolívia e Equador, tanto de regiões onde a herança era antes patrilinear, como bilateral, e no México e no Brasil (Deere \& León, 2001a, Cap. 8), no sentido da herança fundiária estar se tornando mais igualitária em termos de gênero, à medida que as famílias se baseiam menos na agricultura como sua principal atividade. ${ }^{21}$ Esta característica é reforçada pelas altas taxas de migração, e uma tendência, em décadas recentes, para que a migração seja mais equilibrada em termos de gênero, em vez de dominada pelas mulheres como no passado. Sob essas condições, a herança tende a favorecer o filho que ficar em casa, disposto a ser agricultor e cuidar dos pais idosos; isto é, o papel de gênero como filtro nas decisões sobre heranças torna-se menor, comparado com preferências e oportunidades individuais. Essas proposições, é claro, ainda precisam ser testadas empiricamente.

\section{A comunidade}

Outro fator que contribui para a diferença de gênero relativa à propriedade da terra tem a ver com as regras de pertencimento a comunidades camponesas onde a terra é tecnicamente propriedade coletiva. Tanto nos ejidos do México como nas comunidades camponesas e indígenas oficialmente reconhecidas no Peru, a participação em assembléias comunitárias tradicionalmente limitou-se a apenas uma pessoa por lar, o chefe de família. Isso resultou, sobretudo, em apenas os homens terem voz e voto nas assembléias que decidem sobre questões cruciais como a alocação de novas terras (por exemplo, obtidas através da reforma agrária), ou a realocação do patrimônio fundiário da família após a morte de um membro. No México, o Estado determinou as regras de herança nos ejidos e,

21 Apesar de tudo, há exemplos contrários de onde a escassez de terras provocou uma mudança na outra direção, variando desde a herança bilateral à sua concentração nos filhos homens, ou em apenas um deles, a fim de impedir a sua sub-divisão. Por exemplo, sugeriu-se que a fragmentação excessiva de terras no altiplano boliviano, entre os Aimarás, pode ter levado a uma mudança no decorrer do século XX, passando do sistema tradicional de herança bilateral ou paralela, para um que favorece ou o filho mais velho, ou o mais jovem (Arnold \& Yapita, 1997). 
como vimos, essas eram mais favoráveis às esposas do que as normas do código civil. Apesar disso, as assembléias comunitárias dominadas pelos homens eram o árbitro final das disputas sobre herança e, até recentemente, essas tendiam a favorecer os direitos fundiários dos filhos homens, em especial os maiores de idade, acima dos das viúvas (Brunt, 1992; Gonzáles, 1992).

Um processo semelhante caracterizou as práticas de herança dentro das comunidades camponesas peruanas. Conquanto o código civil peruano seja bastante favorável às viúvas - estando essas na primeira ordem de herança, com direitos iguais aos dos filhos - o Estado também reconhece e protege "os costumes, as práticas e tradições da comunidade" (Peru, 1987, Artigo 1). Esses costumes tradicionais têm sido particularmente discriminatórios contra as mulheres. ${ }^{22}$ Como no México, as assembléias comunitárias dominadas pelos homens tendem a favorecer a herança de terras pelos filhos homens sobre a das viúvas, privando as viúvas de quaisquer direitos à terra, se o filho tiver idade para trabalhar (Bonilla, 1997; Coordinadora, 1997). Conforme demonstrado na tabela 3, poucas mulheres conseguiram direitos à terra através de sua distribuição por comunidades indígenas e camponesas.

Além disso, quando os programas neoliberais, na década de 1990, criaram a possibilidade de que terras de propriedade comunitária fossem divididas em parcelas e fossem outorgados títulos individuais, a maioria das mulheres foi excluída da participação nessa decisão crucial quanto ao futuro de suas comunidades, já que essa decisão era a prerrogativa das assembléias comunitárias dominadas pelos homens. No México isso resultou em que aquilo que tinha sido considerado o patrimônio fundiário familiar fosse transformado na propriedade privada individual do homem que era o chefe de família (Botey, 2000; Deere \& León, 2001b; Esparza, Suárez, \& Bonfil, 1996).

22 Veja Deere e León (2001a, Cap 7) para uma discussão detalhada da luta sobre direitos fundiários individuais e coletivos, e como os costumes e práticas tradicionais podem ser prejudiciais às mulheres indígenas. Outros países que não escreveram novos códigos agrários, às vezes estabeleceram mecanismos específicos para a inclusão de mulheres em programas especiais; esses casos são discutidos no texto abaixo. 


\section{O Estado}

A aquisição de terras por meio do Estado, considerada aqui, inclui programas de reforma agrária baseados na expropriação e redistribuição de terras, compra de terras pelo Estado para fins de redistribuição, e escrituração para terras públicas que foram ocupadas por colonização espontânea ou dirigida. O enfoque dos esforços estatais na América Latina variou por país e por época; os esforços de reforma agrária também tiveram escopos muito diversos (Deere \& León, 2001a, Cap. 3; de Janvry, Sadoulet \& Wolford, 2001b). Conforme foi mostrado na tabela 3, entre os atuais proprietários de terras, com a exceção parcial do México, Nicarágua e Peru, a aquisição de propriedade fundiária por esse meio parece relativamente insignificante comparada com herança ou mercado. Isso é em parte relacionado ao número de anos que se passaram desde que a maior parte da terra foi redistribuída. Após uma geração, a propriedade dessa terra provavelmente seria relatada como tendo sido adquirida por herança, em vez de por distribuição estatal. Também se relaciona com o escopo limitado dos esforços de reforma agrária em muitos países. Esta seção enfoca os mecanismos de exclusão e inclusão das mulheres nos esforços estatais de redistribuição de terras.

Dados sobre a proporção de beneficiárias nos 13 programas latino americanos de reforma agrária e colonização, até o período das reformas neoliberais, sugerem que essa modalidade ainda estava em 11-12\% (Deere \& León, 2001a, Tabela 3.2). As mulheres foram em grande parte excluídas dos esforços estatais para a distribuição de terras, até recentemente, por razões legais, culturais ou ideológicas, estruturais e institucionais. Todos esses fatores estão interrelacionados, e têm por base as ideologias patriarcais encaixadas em conceitos de masculinidade e feminilidade. ${ }^{23}$ Aqui enfatizamos os mecanismos de exclusão jurídicos e culturais.

23 Veja Deere (1985), León, Prieto e Salazar (1987), Galán (1998) e Deere e León (2001a, Cap. 3) para exemplos detalhados desses pontos. 
A maioria das leis de reforma agrária parece ser neutra quanto a gênero, pois os beneficiários são definidos em termos de certos grupos sociais, tais como os arrendatários nas fazendas expropriadas, ou trabalhadores sem terra. A barreira legal mais significativa à inclusão de mulheres foi que, embora se tenha pressuposto que as famílias seriam as principais unidades a beneficiar-se, os beneficiários legais eram os chefes de família. As leis, que não designavam explicitamente os chefes de família como beneficiários, estipulavam que apenas uma pessoa por família podia ser beneficiária. Segundo as normas culturais, se houver um homem adulto presente na família, ele será designado o chefe ou representante da família para fins de reforma agrária.

Na década de 1960, a maioria dos códigos civis latino americanos já reconhecia que as mulheres casadas tinham direitos legais de gerir seus próprios bens. Mas os maridos continuavam a ser o único representante da família, e eram responsáveis por administrarem a propriedade e os assuntos econômicos da família. Assim, as reformas agrárias que privilegiavam chefes de família do sexo masculino como beneficiários obedeciam aos códigos civis da época. As mulheres que poderiam ter se beneficiado diretamente das reformas eram chefes de família do sexo feminino, particularmente naqueles países (México, Bolívia e Honduras) que as incluíam especificamente como beneficiárias em potencial. Mas, com poucas exceções, as mulheres rurais representavam uma parte muito maior de chefes de família rurais relatados do que de beneficiários de reforma agrária, sugerindo que outros fatores eram, de fato, barreiras esmagadoras à sua incorporação como beneficiários diretos.

O outro conceito, com grande carga cultural, que permeava essas reformas agrárias, foi de quem seria agricultor. Conforme discutido anteriormente, não importa quanto trabalho as mulheres rurais dediquem à agricultura, esta foi socialmente interpretada como uma ocupação masculina. Por esse motivo, o trabalho feminino na agricultura é, em grande parte, invisível, 
e se chega a ser considerado, é usualmente visto como secundário. Quase todas as leis de reforma agrária favoreciam os agricultores como beneficiários, e sempre se referiam a eles na forma masculina. A linguagem da legislação de reforma agrária, ao não incluir as mulheres explicitamente, reforçou as suposições culturais dos planejadores, comunidades, organizações rurais e beneficiários, a respeito de quem deveria beneficiar-se.

A incorporação de critérios igualitários quanto a gênero, nas leis de reforma agrária latino americanas, tem sido um processo lento. Começou no México, em 1971, quando foram eliminados os critérios discriminatórios contidos na sua legislação de reforma agrária. A Nicarágua, a partir do início de sua reforma agrária em 1981, estabeleceu que os beneficiários deveriam ser selecionados independente de seu sexo e estado conjugal, mas não foram tomadas medidas pró-ativas para assegurar o direito efetivo à terra para as mulheres durante o regime sandinista. O Brasil e a Colômbia, no final da década de 1980, e Honduras no início da década de 1990, também tomaram medidas para modificar disposições até então discriminatórias na sua legislação. Esses três países também foram os líderes regionais na introdução da possibilidade de adjudicação e escrituração conjunta da terra para casais, atendendo a uma demanda que também estava começando a ser ouvida em outros países. Mas seria apenas na década de 1990 que uma confluência de fatores levaria a mudanças nas leis agrárias da maioria dos países, e a uma composição significativamente diferente de beneficiários da reforma agrária por gênero.

Quando os governos neoliberais da América Latina começaram a reescrever os seus códigos agrários na década de 1990 (com um número significativo deles terminando oficialmente suas reformas agrárias), uma série de fundamentos já estavam instalados para assegurar que os novos códigos garantissem pelo menos os direitos formais das mulheres à terra. Em âmbito internacional, o desenvolvimento mais importante foi a ratificação da Convenção de 1979 das Nações Unidas sobre a Eliminação de 
Todas as Formas de Discriminação contra Mulheres. A seção sobre direitos de propriedade tornou claro que os esforços para acabar com a discriminação contra as mulheres devem incluir o reconhecimento dos direitos das mulheres a possuir, herdar e administrar propriedades em seu próprio nome. Os direitos das mulheres à terra eram considerados no contexto de programas de reforma agrária, nos quais as mulheres deveriam receber "tratamento igual" (UN, 1982, Artigos 14-16). As posteriores Conferências Mundiais sobre Mulheres, da ONU, deram cada vez mais atenção aos direitos das mulheres sobre a propriedade da terra, sendo que esses deixaram de ser unicamente um elemento em argumentos sobre eficiência (uma estratégia para aumentar a produtividade das mulheres), para serem tratados como um direito econômico, com o claro reconhecimento da importância da propriedade fundiária das mulheres para o seu empoderamento e a busca de autonomia econômica (Deere \& León, 2001a, p. 114-120).

Em 1990 todas as 19 repúblicas latino-americanas já tinham ratificado a Convenção das Nações Unidas de 1979. A maioria das que ainda não haviam explicitamente previsto a igualdade de gênero nas suas constituições, o fizeram subseqüentemente. A maioria dos países reformou os seus códigos civis e de família, a fim de acabar com a discriminação legal contra as mulheres, em questões relativas à família. Todos menos três países da América Latina agora reconhecem a família de chefia dupla (onde a família é representada tanto pelo marido como pela mulher, e ambos gerem a propriedade comum da família), e todos menos um (Chile) reconhecem uniões consensuais e lhes concedem os mesmos direitos de propriedade que nos casamentos. Esses esforços foram usualmente liderados pelas agências nacionais de mulheres, que também foram fortalecidas durante esse período. A década de 1980 também foi um período de crescimento e consolidação dos movimentos feministas e de mulheres na região. Ambos, em combinação com a proliferação de organizações não-governamentais (ONGs), na década das crises econômicas dos anos 1980, contribuíram 
para a crescente organização das mulheres rurais, em âmbito local, regional e nacional, na América Latina. Como resultado dos esforços daquilo que foi denominado o "triângulo de empoderamento" (a coalizão entre mulheres no Estado, mulheres na política e o movimento de mulheres urbano e rural (Vargas, Wieringa, \& Lyclama, 1996), quando os governos neoliberais criaram espaço para revisar as leis anteriores de reforma agrária, a nova legislação resultante muitas vezes era mais favorável à igualdade de gênero.

Nos novos códigos que seguiam princípios estritamente neoliberais (Equador, Honduras, México e Peru), a propriedade da terra potencial é investida em todas as "pessoas físicas ou jurídicas", implicitamente estabelecendo que homens e mulheres podem ser proprietários de terra e beneficiários de programas estatais. Embora seja um progresso em relação às leis de reforma agrária do passado, que faziam com que apenas os chefes de família fossem os beneficiários, essa legislação não é tão favorável quanto os códigos agrários que estabelecem que homens e mulheres têm direitos iguais à posse da terra e a serem beneficiários de programas estatais, independente de seu estado conjugal. Esses últimos países incluem Bolívia, Brasil, Colômbia, Costa Rica, República Dominicana, Guatemala, Honduras e Nicarágua. ${ }^{24}$

O avanço mais importante a favor da igualdade de gênero é a legislação que contém mecanismos explícitos de inclusão: disposições para a adjudicação e escrituração conjunta de terra para casais obrigatórias e/ou que dão prioridade a chefes de família do sexo feminino, ou a grupos de mulheres específicos (Deere \& León, 2001a, Tabela 6.1). A legislação sobre escrituras conjuntas agora já está estabelecida na Colômbia, Costa Rica, República Dominicana, Guatemala e Nicarágua. Honduras e Brasil inicialmente tornaram opcional essa escrituração conjunta, mas agora ela já é

24 Deere e León (2001a, Cap. 5 e 6). Observe que a legislação hondurenha segue ambas as modalidades, investindo a propriedade da terra em pessoas físicas e jurídicas, ao mesmo tempo que especifica explicitamente que homens ou mulheres podem ser beneficiários, independente da sua situação conjugal. Outros países que não escreveram novos códigos agrários, às vezes estabeleceram mecanismos específicos para a inclusão de mulheres em programas especiais; esses casos são discutidos no texto abaixo. 
juridicamente obrigatória. No Equador e no Peru, a escrituração conjunta foi adotada por decreto administrativo apenas quanto a seus programas de escrituração de terras e, nesse último país, apenas para os casados (Deere \& León, 2001a, Cap. 6 e 9). A escrituração conjunta representa um avanço para a igualdade de gêneros, pois estabelece explicitamente que os direitos de propriedade estão investidos tanto no homem como na mulher que constituem um casal. Na maioria dos países, a escrituração conjunta serve para proteger as mulheres contra a perda de acesso àquele que é, freqüentemente, o bem mais valioso da família, em caso de separação ou divórcio. Em qualquer um dos dois casos, a escrituração conjunta defende um cônjuge contra o outro, caso esse último tome decisões com as quais o primeiro não esteja de acordo, tais como venda, aluguel ou hipoteca da propriedade agrícola. Também protege as viúvas contra serem deserdadas em testamento. Além disso, a escrituração conjunta potencialmente aumenta o poder de barganha das mulheres, valorizando o seu papel na tomada de decisões sobre a família e a propriedade agrícola. Na medida em que a escrituração conjunta promove a estabilidade familiar, foi favorecida não apenas por regimes progressistas, mas também por regimes conservadores que, de resto, estão enamorados de princípios neoliberais que privilegiam os indivíduos.

Outro mecanismo que deverá facilitar o aumento no número de mulheres com propriedade da terra e segurança de posse é a prioridade dada por algumas legislações, tais como aquelas da Colômbia e da Nicarágua, a chefes de família do sexo feminino. Esse é um mecanismo pró-ativo de inclusão, porque busca vencer a discriminação à qual as mulheres chefes de família foram sujeitas no passado, e dá especial proteção às famílias rurais potencialmente vulneráveis. Outra medida pró-ativa de inclusão é a prioridade dada pela legislação colombiana de 1994 a todas as mulheres rurais que se encontram em estado de "falta de proteção", devido à violência que está devastando aquele país. Essa legislação é a que mais inclui 
as mulheres, pois as mulheres desprotegidas constituem um grupo prioritário para os esforços de distribuição de terras, quer sejam mães ou não. Alguns outros países deram atenção especial aos direitos fundiários da mulher dentro de certos grupos, tais como a prioridade de El Salvador, sob os Acordos de paz, às mulheres ex-combatentes na guerra civil, e mulheres posseiras nas zonas de conflito. Sob o Programa de Transferência de Terra (PTT, Programa de Transferencia de Tierra), os direitos fundiários das muIheres eram levados em conta independente de situação conjugal, resultando na adjudicação de parcelas de terra em bases individuais a homens e mulheres que formavam um casal.

Como resultado dessas mudanças legais em países onde a terra ainda estava sendo redistribuída pelo Estado, na década de 1990 a sua distribuição estava se tornando mais eqüitativa em termos de gênero do que no passado. Na Colômbia, Nicarágua, Costa Rica e El Salvador, as mulheres têm representado uma proporção muito maior de beneficiárias de adjudicações de terra recentes, do que nas reformas agrárias de décadas passadas (Deere \& Leon, 2001a, Tabela 10.1). Por exemplo, na Colômbia, em todo o período de reforma agrária desde 1961 até 1991, as mulheres compreendiam apenas $11 \%$ das beneficiárias. Após a adjudicação conjunta a casais ter sido tornada obrigatória (1988) e o cumprimento dessa lei fiscalizado (1995), e também tenha sido dada prioridade à inclusão de famílias chefiadas por mulheres e mulheres desprotegidas, essa proporção aumentou para 45\% durante 1995-1998. Em El Salvador, a proporção de beneficiárias aumentou de 11-12\% durante a reforma agrária, para um terço no programa de transferência de terras associado com os Acordos de Paz.

Um número muito maior de países está atualmente envolvido em programas de escrituração de terras do que na redistribuição das mesmas. Esses programas têm como alvo os beneficiários anteriores da reforma agrária (especialmente aqueles nos quais a terra tinha, anteriormente, sido 
adjudicada coletivamente, seja para cooperativas de produção ou para comunidades camponesas, e, como resultado da legislação neoliberal, pode agora ser dividida em parcelas); posseiros em terras do governo nacional; e o grande setor de pequenos proprietários tradicionais, com insegurança de posse. Países que adotaram mecanismos progressivos de inclusão em termos de gênero para esses programas, tais como o Chile e o Equador, têm uma proporção muito maior de beneficiárias de esforços de escrituração de terras do que aqueles que não os adotaram, tais como Honduras e México (Deere \& León, 2001a, 2001b).

\section{O mercado}

Se o mercado de terras fosse neutro em termos de gênero, seria de se esperar que as mulheres rurais pobres enfrentassem um número de obstáculos não maior do que aquele enfrentado por homens rurais pobres. $\mathrm{Na}$ qualidade de compradores, os camponeses pobres estão submetidos a recursos financeiros limitados e falta de acesso ao crédito em condições que possam pagar. Além disso, os homens e mulheres rurais pobres seriam igualmente desencorajados de participar no mercado de terras pelos elevados custos de transação e preços relativamente elevados para as terras, resultantes de restrições de suprimento nesse mercado, tal como a oferta limitada de terras a venda. Ademais, se o mercado de terras fosse neutro em termos de gênero, esperaríamos que homens e mulheres pudessem comprar terras de qualidade e quantidade semelhantes, a um preço semeIhante. Como vendedores, esperaríamos que os proprietários camponeses, fossem eles homens ou mulheres, oferecessem as suas terras para venda por motivos semelhantes, e com o mesmo desfecho. Por exemplo, nós esperaríamos que um dos efeitos dos programas de titulação de terras seria aumentar o valor de terras escrituradas comparado com terras de qualidade similar, sem escritura. Se as motivações para participar no mercado 
fundiário fossem neutras em termos de gênero, esperaríamos que proprietários do sexo masculino e feminino oferecessem as suas terras à venda por preços semelhantes. Se, por outro lado, homens e mulheres valorizam a propriedade de terras por motivos diferentes ou têm acesso diferente aos outros recursos necessários para serem agricultores produtivos e eficientes, a participação como vendedores poderá ser significativamente diferente por gênero.

Às vezes se afirma ser mais provável que mulheres proprietárias vendam suas terras do que os homens, pois é menos provável que alcancem sucesso na agricultura, dada a discriminação enfrentada pelas agricultoras no acesso ao crédito, assistência técnica, etc. (Deere \& León, 2001a, p. 327-328). As poucas evidências disponíveis não são claras, e referem-se sobretudo à participação em mercados de aluguel de terras, por beneficiários recentes dos projetos de titulação de terras da década de 1990. Um estudo de caso de agricultores em quatro ejidos, numa região comercialmente vibrante do norte do México, verificou que $70 \%$ deles estavam alugando as suas terras em 1999, muitos como prelúdio à venda de suas parcelas. ${ }^{25}$ As ejidatárias tinham maior probabilidade $(87 \%)$ de alugar as suas terras do que os seus equivalentes masculinos (62\%), sendo esta diferença estatisticamente significativa, no nível de confiança de 95\% (Lewis, 2002). A nossa análise do levantamento dos beneficiários de titulação de terras (outorga de título de terras), no Chile, constatou que poucos homens ou mulheres haviam alugado, vendido ou cedido suas terras depois de receber o título (apenas $2.7 \%$ do total), e que não havia diferença estatisticamente significativa por gênero, quanto a aqueles que planejavam vender, alugar (arrendar) ou ceder suas terras a outros no futuro próximo (5.6\% do total). Mes-

25 A privatização de terras de ejido envolve dois passos. O primeiro consiste na certificação e escrituração pelo PROCEDE, o que permite ao ejidatário arrendar a sua terra ou vende-la a outro ejidatario. Essa terra continua a fazer parte do regime de ejido. O segundo passo, a conversão em propriedade privada de pleno domínio (domínio pleno), de modo que a terra possa ser vendida a pessoas de fora, requer uma votação com dois terços de maioria, pelos membros do ejido. Esse processo envolve uma série de custos, e a terra pode então ser tributada, o que poderá explicar por que poucos ejidos foram convertidos em propriedade privada de pleno domínio, e por que arrendar as terras tem sido o desfecho mais comum do processo de divisão em parcelas nas regiões de agricultura comercial, tais como no norte do México. 
mo que as perspectivas das mulheres de se tornar agricultoras comerciais bem sucedidas sejam mais restritas do que para os homens, as mulheres também valorizam a posse de terras por outros motivos: a segurança que Ihes oferece em termos de cobrir as necessidades mínimas de alimento de sua família; o valor geral de serem proprietárias de um bem que podem arrendar ou trabalhar em parceria quando necessário; e o poder de barganha que lhes dá dentro da casa, da família e da comunidade.

Os dados sobre as formas de aquisição de propriedade por gênero, apresentados na tabela 3, sugerem que os homens têm maior probabilidade do que as mulheres de participar com sucesso no mercado fundiário, na qualidade de compradores. Um motivo pelo qual o mercado pode ser uma fonte menos importante de aquisição de terras para mulheres, sugerido por estudos de caso, é a discriminação direta contra as mulheres. Deere (1990, p. 199-201) verificou que, na venda de terras de haciendas, nas décadas de 1950 e 1960, na serra do norte do Peru, as mulheres tendiam a comprar parcelas de terra menores e pagavam preços mais altos do que os homens, por terras de dimensões e qualidade semelhantes. Isso reflete o menor poder de barganha das mulheres, um produto de estereótipos e papéis atribuídos ao gênero, ilustrado por seu maior grau de subserviência aos donos das terras e fomentado por seu desespero de comprar terra quando estava disponível para venda. A participação das mulheres como compradoras, todavia, dependia da predileção daqueles que ofereciam terras à venda, alguns donos de terra recusando-se a vender terras para mulheres, ilustrando algumas das formas pelas quais o mercado fundiário não é neutro em termos de gênero.

Entre os outros fatores que explicam a participação desigual no mercado fundiário, segundo o gênero, estão as rendas relativas (particularmente a capacidade de gerar poupança), e/ou acesso ao crédito, que, por sua vez, são condicionadas pelas oportunidades de geração de renda disponíveis para homens e mulheres. Isto é, distorções no mercado de traba- 
Iho e de crédito podem produzir distorções com viés de gênero também no mercado fundiário. A literatura abundante sobre mercados de trabalho rurais, na América Latina, demonstrou as diferenças persistentes na participação de homens e mulheres no mercado de trabalho agrícola, sendo que os homens têm acesso muito maior a oportunidades de emprego permanente do que as mulheres. Mesmo em casos nos quais se prefere mão de obra feminina para certas tarefas ou culturas, o emprego feminino é concentrado, avassaladoramente, em tarefas sazonais ou temporárias. Além disso, quando homens e mulheres são empregados para atividades semelhantes, as mulheres tendem a receber pagamento mais baixo do que os homens. ${ }^{26}$ Considerando os baixos pagamentos que caracterizam o trabalho agrícola, e o padrão de emprego para mulheres, poucas mulheres rurais geram poupança suficiente para participar no mercado fundiário como compradoras.

Com respeito à disponibilidade de crédito para a aquisição de terra, até recentemente, poucos programas estatais de crédito agrícola da América Latina forneciam empréstimos para a compra de terras, e geralmente não eram desenvolvidas atividades hipotecárias dentro do sistema financeiro privado. Quando existia um mercado hipotecário rural, ele geralmente era organizado em função dos interesses dos grandes agricultores comerciais. Nas duas últimas décadas, tem crescido o interesse entre agências internacionais, governos e ONGs, em realizar tentativas com programas de crédito fundiário orientados para os pobres rurais. As evidências limitadas provenientes desses programas sugerem que as mulheres não se deram muito bem. Num dos mais antigos e bem-sucedidos desses programas, FEPP (Fondo Ecuatoriano Populorum Progresso), na serra do Equador, orientado para chefes de família, as mulheres representavam 14\% dos beneficiários diretos durante 1990-95 (Navarro, Vallejo, \& Villaverde, 1996, p. 168), uma parte relativamente pequena, se comparada com a importância relativa de compras de terras por mulheres no Equador (Tabela 3). 
Dados sobre outro programa do setor privado, dirigido pela Penny Foundation na Guatemala, e apoiado pela Agency for International Development, dos Estados Unidos, são ainda piores: as mulheres consti-túam apenas 1\% dos beneficiários diretos desse programa (Fundación Arias \& Terra Viva, 1993, p. 130-136).

Essas iniciativas do setor privado sugerem que, a não ser que exista um conteúdo explícito de gênero, os programas de compras de terras no mercado, em si, pouco farão para aumentar o número de mulheres proprietárias. Muitos dos mesmos fatores - culturais, estruturais e institucionais que constituíam mecanismos de exclusão das mulheres em programas estatais de reforma agrária, criaram um viés contra a sua participação nesses programas. Além disso, esses fatores podem até ser agravados nos programas setoriais privados, já que eles freqüentemente devem operar em termos quase comerciais. Na medida em que se dá maior ênfase à necessidade dos beneficiários poderem receber crédito e engajar-se estritamente em atividades comerciais, e pagar as suas hipotecas, isso afetará negativamente a participação das mulheres, pois é difícil que elas consigam preencher essas exigências sob as mesmas condições que os homens. ${ }^{27}$

Uma das lições da experiência colombiana de "reforma agrária" conduzida pelo mercado ${ }^{28}$ é que, para que as mulheres se beneficiem diretamente de tais programas, é necessária uma política estatal explícita favorecendo a sua participação. Entre os mecanismos de inclusão exigidos estão disposições para a alocação e escrituração conjunta de terras a casais, e medidas de ação afirmativa tais como as que priorizam mulheres como chefes de família, além de substancial suporte do Estado. Devido a essas medidas, durante a experiência colombiana de "reforma agrária" conduzida pelo mercado, de vida relativamente curta, $68 \%$ das compras subsidiadas foram feitas por casais, $20 \%$ por homens individuais, e $12 \%$ por

27 As mulheres também podem ser mais avessas a risco do que os homens, mas poucas pesquisas foram feitas sobre esse assunto, na América Latina.

28 Semelhante ao Banco da Terra, no Brasil, que oferece crédito para a aquisição de terras através do mercado, com base em financiamento do Banco Mundial. 
mulheres individuais (Deere \& León, 2001a, Tabela 6.2). Conquanto os homens individuais tenham se beneficiado mais do que as mulheres individuais, a prioridade dada à adjudicação e escrituração conjunta significou que as mulheres constituíram $48 \%$ dos beneficiários diretos totais.

Por outro lado, no programa experimental do Banco da Terra, no Brasil, que não tinha medidas específicas para a inclusão de mulheres, elas constituíram apenas 12\% dos beneficiários durante 1998-1999, mais ou menos a mesma proporção de beneficiárias que no programa normal de reforma agrária (Deere, 2003). Em 2001, o Ministério de Desenvolvimento Agrícola criou um departamento de ação afirmativa, e uma de suas metas era de reformular todos os critérios e normas para facilitar o acesso das mulheres rurais a terras e escrituras, treinamento, assistência técnica e benefícios de previdência social. Uma de suas primeiras medidas foi um decreto administrativo visando $30 \%$ do crédito para compras de terras no programa expandido do Banco da Terra (Fundo de Terras e da Reforma Agrária) para mulheres (Deere, 2003). Essa medida é inovadora, pois é a primeira vez que um sistema de quota foi proposto como mecanismo de inclusão de mulheres em um programa de distribuição de terras, mas, de acordo com nosso conhecimento, não se implementou na prática.

Finalmente, há ampla evidência do interesse das mulheres rurais em participar do mercado de terras devido a todos os benefícios conferidos pela propriedade da terra. A aquisição de uma parcela de terra própria é amplamente reconhecida como uma das melhores formas de segurança para mulheres e seus filhos, e como meio de obter alguma autonomia econômica. As mulheres rurais muitas vezes fazem um grande esforço para tentar comprar terras, inclusive poupando os seus parcos ganhos durante muitos anos, enquanto trabalham como empregadas domésticas em áreas urbanas (Fundación Arias \& Terra Viva, 1993, p. 72-73). Estudos de caso realizados no México relatam que adquirir terras próprias é, às vezes, até mesmo uma aspiração de mulheres jovens e solteiras, cujo nível de instru- 
ção mais elevado lhes permitiu obter emprego fora do setor agrícola. Elas se dão conta do potencial aumento do poder de barganha, que é conferido, dentro do casamento, pela propriedade de bens, especialmente de terra (Castañeda, 2002).

\section{A diferença de gênero no tamanho da propriedade agrícola}

Independentemente de como foi adquirida a terra, a desigualdade de gênero em termos do tamanho das propriedades é a norma na América Latina, conforme foi observado internacionalmente (Quisumbing, 1998, p. 263). Como mostra a tabela 5, para oito países onde há dados disponíveis, os proprietários sempre tendem a possuir mais terras, em média, do que as proprietárias. ${ }^{29} \mathrm{O}$ problema, em termos de chegar a qualquer conclusão firme quanto à diferença de gênero no tamanho da propriedade agrícola, é que essas aparentes diferenças de gênero nem sempre são estatisticamente significativas. Na Tabela 5, para os quatro países cujos dados estavam em condições de serem testados, os testes t revelaram que a diferença de gênero não era estatisticamente significativa em três (Brasil, Paraguai e Peru). No Peru isso se deve ao fato de que as famílias que têm mais terras como propriedade mista ou conjunta são proprietárias de mais terras do que as relativas a propriedades individuais de mulheres ou de homens separadamente. No Paraguai, onde vale o contrário, a diferença na quantidade de terras possuídas por famílias nas quais as mulheres têm alguns direitos de propriedade, versus aquelas nas quais elas têm nenhum, era estatisticamente significativa apenas ao nível de confiança de 90\%.

Vários fatores, contudo, explicam a tendência geral para a desigualdade de gênero no tamanho da propriedade agrícola, entre eles a média de

29 Além disso, os dados de censo agrícola para o Peru e o Paraguai demonstram que as agricultoras ou têm menos terras no todo, ou estão super representadas entre aqueles agricultores que têm acesso a menos de 10 ha de terra (INEL, 1995; Paraguai, 1993). Só não houve aparentes diferenças de gênero entre os pequenos proprietários no censo de 1979 da Guatemala (Guatemala, 1985, Tabela 11). 
idade dos proprietários e a forma pela qual as mulheres tendem a adquirir a terra. Em quase todos os casos, as agricultoras tendem a ser mais velhas, em média, do que os agricultores, refletindo a proporção relativamente maior de mulheres que se tornam proprietárias apenas depois de viúvas. Por exemplo, entre os ejidatários com terras escrituradas, no México, 68\% das mulheres tinham mais de 50 anos de idade, comparado com apenas $54 \%$ dos homens (Robles et al., 2000, p. 21). No levantamento chileno sobre beneficiários da titulação de terras, 56\% das proprietárias tinham mais de 50 anos de idade, comparado com 51\% dos homens, e essa diferença era estatisticamente significativa ao nível de confiança de $99 \%{ }^{30}$

Outro fator é que as mulheres muitas vezes tendem a herdar terras como resultado de práticas de partilha de herança, seja herdando terra como viúvas juntamente com os seus filhos, ou como filhas, nos casos em que todos os filhos herdaram parte da terra. Em qualquer um dos dois casos, a quantidade média da terra herdada é menor do que quando a terra é legada a apenas um herdeiro. Quando é escolhido apenas um herdeiro, conforme observado anteriormente, é bem mais provável que seja um filho do que uma filha. Além disso, existe ampla evidência anedótica de que, quando tanto filhos como filhas herdam terra, os filhos sempre herdam não apenas mais, como a terra que herdam é de melhor qualidade (Deere \& León, 2001a, Cap. 8). Motivos semelhantes àqueles que excluem as mulheres dos direitos de herança de terras governam a desigualdade de gênero na quantidade e qualidade relativas de terras herdadas pelos filhos. A socialização de gênero e a expectativa de que filhos, mais do que filhas, serão agricultores, combinado com a lógica da reprodução da família camponesa, têm sido fatores potentes que concentram a terra na linha masculina, mesmo em regiões caracterizadas por práticas de herança bilaterais. A tendência para a desigualdade no tamanho da propriedade

30 A tendência das proprietárias serem mais velhas do que os proprietários vale, também, no caso peruano, sendo que $58 \%$ das primeiras, mas apenas $44 \%$ dos últimos têm mais de 50 anos de idade, sendo essa diferença estatisticamente significativa. Dos casos nos quais pode ser testada a significância estatística da diferença de idade, por gênero, apenas no Paraguai não foi significativa, $61 \%$ das agricultoras e $58 \%$ dos agricultores tendo mais de 50 anos de idade. 
fundiária, em herança, também é relacionada à expectativa de que as filhas apenas necessitam de terras para satisfazer necessidades de alimento mínimas ou complementares, já que seus maridos proverão as suas famílias com acesso à terra, ou renda suficiente para satisfazer as necessidades básicas da família.

Tabela 5. Diferenças de gênero na quantidade de terra em propriedade, anos 1990s (em hectares)

\begin{tabular}{|c|c|c|c|c|c|c|c|c|}
\hline País & Brasil $^{\mathrm{a}}$ & Chile $^{\mathrm{b} * * *}$ & Colômbia $^{\mathrm{c}}$ & Equador $^{\mathrm{d}}$ & Honduras $^{\mathrm{e}}$ & México $^{\mathrm{f}}$ & Paraguai $^{\mathrm{q} *}$ & Peru $^{\mathrm{h}}$ \\
\hline Mulheres & 302.7 & 4.6 & 13.4 & 0.81 & 4.2 & 7.9 & 23.6 & 4.7 \\
\hline Homens & 310.8 & 6.0 & 17.7 & 1.15 & 5.4 & 9.0 & 34.4 & 5.5 \\
\hline $\begin{array}{c}\text { Propriedade } \\
\text { Conjunta }\end{array}$ & NA & NA & 14.5 & 1.21 & NA & NA & 20.9 & 6.8 \\
\hline $\mathrm{n}$ & 22,865 & 683 & 13,200 & 12,416 & 110,162 & $1.4 \mathrm{~m}$ & 1,694 & 871 \\
\hline
\end{tabular}

Notas e fontes:

$\mathrm{NA}=$ Não foi perguntado na pesquisa ou não era uma opção (México).

* Teste T estatisticamente significativo ao nível de $90 \%$.

** Teste T estatisticamente significativo ao nível de $95 \%$.

a Dados referentes a propriedades com mais de 50 hectares, extraídos do Censo Comunitário Rural 2000, op. cit.; a diferença entre proprietários dos sexos masculino e feminino não foi significativa.

${ }^{\mathrm{b}}$ Dados referentes a parcelas de terra com mais de 5,000 $\mathrm{m}^{2}$, extraídos da pesquisa do programa de titulação de terras, 1992-96, op. cit.

c Dados dos programas de reforma agrária, 1996-98, compilados dos dados fornecidos pelo INCORA, Bogotá, Julho de 2000 .

${ }^{d}$ Dados do programa de titulação de terras do PRONADER em 12 zonas, 1992-96, compilados de dados fornecidos pelo Consejo Nacional de las Mujeres, Quito, agosto de 1997.

e Dados do programa de titulação de terras no setor não reformado, 1995-2000, com o relato de um número insignificante de proprietários conjuntos; compilados dos dados fornecidos pelo Instituto Nacional Agrario, Tegucigalpa, janeiro de 2001. ${ }^{f}$ Programa de titulação de terras do setor de ejidos, 1993-99 (Robles et.al., 2000, p. 23).

g Dados extraídos da pesquisa LSMS, MECOVI, 2000-01, op. cit; não foram encontradas diferenças estatisticamente significativas entre proprietários homens, mulheres, mistos ou conjuntos, mas a diferença entre famílias com ou sem mulheres com direitos sobre a terra foi significativa ao nível de $90 \%$.

h Dados extraídos da pesquisa LSMS, ENNVI 2000, op. cit.; não foram encontradas diferenças estatisticamente significativas entre proprietários homens, mulheres, mistos ou conjuntos ou entre famílias com ou sem mulheres com direitos sobre a terra. 
Essa mesma lógica permeou a distribuição de terras pelo Estado. Conforme discute Rocha (1998, p. 40), no caso da reforma agrária nicaragüense, a quantidade desigual de terras recebidas por homens e mulheres foi o resultado de "discriminação inconsciente" quanto à divisão do trabalho por gênero: "Pressupõe-se que as mulheres não necessitam de maiores quantidades de terra do que aquela necessária para produzir a segurança alimentar da família". Um viés semelhante quanto a gênero pode operar no mercado fundiário, com proprietários pressupondo que as mulheres necessitem de menores quantidades de terra do que os homens, juntamente com os recursos relativamente mais limitados das mulheres para a compra de terras quando oferecidas à venda. Todos esses fatores, somados, ajudam a explicar a tendência de relativa desigualdade na quantidade de terra de agricultores e agricultoras.

\section{Conclusão}

A desigualdade de gênero na distribuição de bens na região rural da América Latina é substancial. Terra, o bem mais importante do campesinato, geralmente é propriedade masculina e, além disso, quando tanto homens como mulheres possuem terras, os homens tendem a possuir parcelas maiores e de melhor qualidade. Discutimos que a desigualdade de gênero na propriedade da terra se deve à preferência masculina na herança, ao privilégio masculino no casamento, e ao viés de gênero em programas de distribuição de terras da comunidade e do Estado. Também há evidências de viés de gênero no mercado fundiário, que, quando combinado com distorções no mercado de trabalho e de crédito, leva as mulheres a serem relativamente menos bem sucedidas como compradoras no mercado fundiário comparado aos homens. Nessa seção final, em primeiro lugar resumimos as tendências recentes na América Latina, que favorecem a eqüidade de gênero na distribuição de terras, e depois discutimos a agen- 
da de pesquisas derivada desta revisão.

No decorrer do século XX, o arcabouço jurídico gradativamente expandiu os direitos de propriedade das mulheres casadas, e aquelas de uniões consensuais. A recente adoção da figura jurídica da família, com chefia dupla, fortaleceu a possibilidade de que os bens adquiridos durante o casamento realmente sejam de propriedade conjunta e assim administrados. Essa mudança fortalece a posição de retaguarda das mulheres, já que aumenta a probabilidade de que, caso se separem, se divorciem ou fiquem viúvas, possam garantir a metade da propriedade comum à qual têm direito nos termos da maioria dos regimes de casamento. Em segundo lugar, com a diminuição do analfabetismo, tanto entre homens como muIheres do meio rural, cresceu o conhecimento jurídico, as mulheres em particular conscientizando-se dos seus direitos de herança como filhas e viúvas. Apesar disso, persiste a diferença de gênero na alfabetização (Valdés \& Gomáriz, 1995, p. 100) e as mulheres rurais muitas vezes têm dificuldade em reivindicar os seus direitos legais devido à falta de documentação legal. ${ }^{31}$

Embora muito também reste a ser feito em termos de garantir os direitos legais das viúvas ${ }^{32}$ à herança, existem evidências, em certos países, de que as práticas de herança podem estar começando a fortalecê-las, dando-lhes primazia acima dos seus filhos. Essa tendência está associada à crescente diferença de gênero na expectativa de vida, por um lado, e ao declínio das redes familiares e comunitárias que outrora proporcionavam seguridade social aos idosos, por outro, combinada com a falta de direitos formais de seguridade social em áreas rurais na maioria dos países. Uma tendência para o aumento da herança de terras por viúvas é importante, não apenas em termos de aumentar a quantidade absoluta de terra que é

31 É necessária documentação legal, tal como um título eleitoral no Peru, ou um registro de identidade ou do imposto de renda no Brasil, para ser beneficiário de programas estatais de titulação ou distribuição de terras, respectivamente. Por esse motivo, uma série de associações de mulheres rurais lançaram campanhas nacionais para incentivar as mulheres rurais a obterem documentos pessoais. Sobre o Brasil, veja Deere (2003).

32 O principal problema é que, em uma série de países, as viúvas não herdam automaticamente do espólio do seu marido, a não ser que consigam comprovar uma necessidade econômica. Esses problemas e potenciais reformas para favorecer as viúvas são discutidos em Deere e León (2001a, 2001c). 
de propriedade e controlada por mulheres e sua autonomia econômica, mas também por aquilo que promete em termos de apoiar uma cultura de igualdade nas práticas da herança da terra pelos filhos.

A crescente eqüidade de gênero na transmissão de terras aos filhos através da herança foi associada com um aumento na prática da divisibilidade da herança, ela própria ligada à família de tamanho menor. Além disso, encontra-se cada vez mais a transmissão da herança a filhas, em regiões onde a migração é mais ou menos equilibrada em termos de gênero, e quem herda terras é crescentemente associada com a disponibilidade de permanecer no campo, cuidando dos pais na sua velhice. Também está associada a regiões onde a agricultura camponesa está em declínio (seja devido à falta aguda de terras e/ou políticas estatais desfavoráveis), e não é mais capaz de garantir a sustentabilidade do meio de vida com base apenas na produção agrícola. Nesses contextos, a terra não apenas constitui um valor econômico em declínio, como também perdeu posição como uma fonte de poder político dentro das comunidades rurais, minando a lógica precedente da reprodução de famílias camponesas, que concentrava a terra em um só filho. Mas essas propostas requerem mais pesquisas empíricas.

O acesso à terra por meio da distribuição e titulação pelo Estado também se tornou mais eqüitativo em termos de gênero na última década, devido à adoção, por uma série de países, de mecanismos de inclusão de mulheres nesses programas, tais como a escrituração conjunta obrigatória de terras para casais, e medidas pró-ativas, tais como prioridade para chefes de família do sexo feminino ou quotas para mulheres. Apesar disso, continua a haver uma disjunção substancial entre os direitos legais da mulher no tocante à terra, e sua propriedade da terra propriamente dita, uma lacuna que é pouco provável que se feche por meio da ação do Estado, pois na maioria dos países os programas de reforma agrária já foram concluídos. A prioridade atual da maioria dos governos é de ativar os merca- 
dos fundiários, em grande parte por programas de titulação de terras com vistas a garantir a segurança da posse. Nos países que adotaram mecanismos de inclusão das mulheres nos programas de titulação de terras, elas estão surgindo como uma proporção maior dos beneficiários do que em países onde se pressupõe que tais programas sejam indiferentes em relação ao gênero. Apesar de tudo, em princípio, os programas de escrituração de terras apenas beneficiam aqueles que são atualmente proprietários e não tratam das desigualdades fundamentais da atual distribuição de terras da América Latina, ou desigualdades de classe e gênero na forma de aquisição da terra.

Os mercados fundiários raramente favorecem os pobres rurais (Carter \& Barham, 1996; Carter \& Salgado, 2001); como demonstramos, também não são neutros em termos de gênero. Assim, é particularmente preocupante o fato de que, em uma série de países, o mercado fundiário esteja se tornando o principal meio através do qual se pode adquirir terra. Se os bancos da terra - com grandes subsídios estatais para a compra de terras se tornarem o principal meio através do qual camponeses e camponesas pobres podem aspirar a adquirir terras, serão necessárias medidas próativas para assegurar a igualdade de resultados para homens e mulheres. $\mathrm{O}$ problema fundamental é que a terra continua a ser tão desigualmente distribuída na América Latina como sempre foi, e tendências recentes sugerem que, segundo o modelo neoliberal dominante, a terra está se tornando ainda mais concentrada (David, Morales \& Rodriguez, 2001). Assim, avanços recentes em igualdade de gênero na distribuição de terras entre os camponeses estão ocorrendo em um contexto socialmente muito regressivo, que não apresenta boas perspectivas, seja para o futuro do campesinato ou para avanços sustentados no sentido da equidade de gênero.

Um problema importante para levar adiante o estudo de gênero e direitos de propriedade da terra é que os censos agrícolas e a maioria dos 
principais conjuntos de dados agora coletados na América Latina dão pouca ou nenhuma atenção à propriedade de bens segundo gênero, ou como os mesmos são adquiridos. Conforme sublinhamos, a questão crítica é quem, dentro da família, é o proprietário legal das diferentes parcelas de terra que constituem a propriedade agrícola da família. Não se pode pressupor, simplesmente, que o proprietário de uma fazenda operada pelo proprietário seja o chefe da família; é importante levar em conta que as terras podem ser propriedade conjunta de marido e mulher, ou de vários membros da família. Além disso, existem, nos diferentes países, regimes de casamento diversos, com diferentes regras sobre a quem pertencem propriedades adquiridas antes e depois do casamento. Todos esses fatores devem ser levados em conta em qualquer estudo rigoroso sobre a distribuição da posse de propriedades por gênero.

A falta de dados apropriados impôs grandes limitações na análise potencial da relação entre a diferença de gênero no controle dos recursos e a pobreza, distribuição e crescimento de renda. ${ }^{33}$ É bastante claro que o acesso à terra, mesmo a uma parcela muito pequena, permite que as muIheres dêem à sua família pelo menos uma parte mínima de suas necessidades de subsistência, talvez impedindo que fiquem na miséria, particularmente quando essa parcela é de sua propriedade e está sob seu controle. Além disso, enquanto a posse de pelo menos uma pequena parcela de terra está associada com estratégias de geração de renda mais diversificadas entre os pobres rurais, o que deverá atenuar a miséria (Agarwal, 1994; de Janvry et al., 2001a, 2001b), ainda resta a ser comprovado que a propriedade da terra de per si mantenha uma família rural fora da pobreza, e que o gênero do proprietário faça alguma diferença. Pensamos que possa, e isto deveria estar entre os itens principais na agenda de pesquisas.

Cada vez mais, a posse de bens pelas mulheres é importante, não

33 Há um corpo de evidências crescente ligando as reduções na desigualdade de gênero tanto ao crescimento como à melhor distribuição de renda (Banco Mundial, 2000, p. 56). Apesar disso, relativamente poucas pesquisas foram realizadas sobre o potencial impacto de reduções de desigualdade de gênero sobre a distribuição de bens produtivos em níveis de miséria ou desigualdade de renda. Esta lacuna é, em parte, devida à escassez de dados desagregados por gênero, sobre a distribuição de bens tais como terra. 
apenas para estabelecer a igualdade real, ao contrário de meramente formal, entre homens e mulheres, mas também porque a posse de terras pelas mulheres rurais está estreitamente associada com o seu bem estar e empoderamento. Por detrás de nossa análise está a suposição de que a posse de terras pelas mulheres esteja associada com o aumento do seu poder de barganha dentro da família e da comunidade, porque a posse da terra valoriza a posição de retaguarda das mulheres (Agarwal, 1994). Há um corpo crescente de evidências de estudos de caso da América Latina, demonstrando que, se compararmos proprietárias camponesas com aquelas que não possuem terra, as proprietárias têm muito maior escolha de parceiros no casamento e conseguem uma posição muito mais forte ao negociar o seu casamento. Dentro do casamento, as proprietárias desempenham um papel muito maior, tanto na tomada de decisões referentes à casa e à propriedade, inclusive decisões sobre produção e aquelas que governam a destinação daquilo que é produzido, e como é usada a renda assim gerada. A posse da terra pelas mulheres também foi associada com menores taxas de violência doméstica, pois as proprietárias estão em posição muito melhor para abandonar um parceiro abusivo, devido a sua posição mais forte na retaguarda; também lhes é mais fácil atrair outro cônjuge. As proprietárias derivam uma série de benefícios específicos adicionais devido à sua posse de bens na velhice, tanto devido à sua potencial autonomia econômica, como porque é mais provável que possam exigir o auxílio de seus filhos (Deere \& León, 2001a, p. 28-30). Contudo, ainda resta a ser feito um teste empírico rigoroso dessas propostas no caso latino americano. Além disso, deve ser dada particular atenção à interação de dinâmica de gênero e de classe, ao analisar-se tais desfechos.

\section{Referências}

AGARWAL, B. A field of one's own: gender and land rights in South Asia. 
Cambridge: Cambridge University Press, 1994.

ARNOLD, D.; Yapita, J. de D. La lucha por la dote en un ayllu andino. In: Arnold, D., (Ed.). Mas allá del silencio: Las fronteras de género en los Andes. La Paz: ILCA/CIASE, 1997, p. 345-383.

ARROM, S.M. The women of Mexico City 1790-1857. Stanford, CA: Stanford University Press, 1985.

BAITENMANN, H. Rural agency and state formation in post-revolutionary Mexico: the agrarian reform in Central Veracruz (1915-1992). Unpublished doctoral dissertation. New York: New School for Social Research, 1997.

BEYER ESPARZA, J. E. Mujer y tierra social: la experiencia Mexicana y la insuficiencia de los mecanismos formales en la superación de la inequidad de género. Comment prepared for the World Bank Regional Workshop on Land Issues in Latin America and the Caribbean, Pachuca, Hidalgo, Mexico, May, 2002.

BONILLA, J. Tercer intento modernizador. In: Colectivo de Autores (Eds.). Segundo encuentro regional por la agricultura: Contexto económico y pequeña producción rural Andina. CuzCo, Peru: COINCIDE, 1997, p. 67-74.

BOTEY, C. Mujer rural: Reforma agraria y contrareforma. In: Aranda, J.; Botey, C.; Robles, R. (Eds). Tiempo de crisis, tiempos de mujeres. Oaxaca, México: Centro de Estudios de la Cuestión Agraria Mexicana, Universidad Autónoma Benito Juárez de Oaxaca, 2000, p. 95-154.

BRUNT, D. Mastering the struggle: gender, actors and agrarian change in a Mexican ejido. Amsterdam: Centro de Estudios y Documentación Latinoamericanos, 1992.

CARNEIRO, M.J. Herança e gênero entre agricultores familiares. In: Estudos Feministas, v. 9, n. 1, 2001, p. 22-57.

CARNEIRO, M. J.; de Freitas, D.; Guedes, G. Valor da terra e padrão de herança entre pequenos agricultores familiares. Paper presented at the 21st meeting of the Associação Brasileira de Antropologia, Vitória, Salvador, Brasil, Abril, 1998.

CARTER, M.; Barham, B. Level playing fields and laissez faire: post-liberal development strategy in inegalitarian agrarian economies. In: World Development, 
v. 24 , n. 7, 1996, p. 1133-1150.

CARTER, M.; Salgado, R. Land market liberalization and the agrarian question in Latin America. In: de Janvry, A.; Gordillo, G.; Platteau, J.; Sadoulet, E. (Eds). Access to land, rural poverty, and public action. Oxford: Oxford University Press, 2001, p. 246-278.

CASTAÑEDA, S. M. P. Identidad femenina y herencia: algunos cambios generacionales. In: da Gloria Marroni, M.; D'Aubeterre, M. E. (Eds). Con voz propia: mujeres rurales en los 90. Puebla: Benemérita Universidad Autónoma de Puebla, 2002, p. 95-123.

Coordinadora Nacional de Comunidades Campesinas, Grupo de Trabajo sobre Comunidades y Titulación. Derechos individuales al interior de la comunidad. Paper presented to the Primer Taller sobre Comunidades Campesinas y Titulación, Lima, June, 1997.

CÓRDOVA PLAZA, R. Gender roles, inheritance patterns, and female access to land in an ejidal community in Veracruz, Mexico. In: Zoomers, A.; van der Haar, G. (Eds). Current land policy in Latin America: regulating land tenure under neo-liberalism. Amsterdam: Royal Tropical Institute, 2000, p. 161-173.

COUTURIER, E. Women and the family in eighteenth century Mexico: law and practice. In: Journal of Family History, v. 10, n. 3, 1985, p. 294-304.

DAVID, M. B. de A.; Morales, C.; Rodríguez, M. Modernidad y heterogeneidad: estilo de desarrollo agrícola y rural en América Latina y el Caribe. In: David, M. B. de. A. (Ed). Desarollo rural en América Latina y el Caribe. Santiago: CEPAL, 2001.

DEERE, C. D. Rural women and state policy: the Latin American agrarian reform experience. In: World Development, v. 13, n. 9, 1985, p. 1036-1053.

DEERE, C. D. Household and class relations: peasants and landlords in Northern Peru. Berkeley: University of California Press, 1990.

DEERE, C. D. Women's land rights and rural social movements in the Brazilian agrarian reform. In: Journal of Agrarian Change, v. 3, n. 1-2, 2003, p. 257-288. 
DEERE, C. D.; León, M. Women in Andean agriculture: peasant production and rural wage employment in Colombia and Peru. Geneva: International Labour Office, 1982.

DEERE, C. D.; León, M. (Eds). Rural women and state policy: feminist perspectives on agricultural development in Latin America. Boulder, CO: Westview Press, 1987.

DEERE, C. D.; León, M. Empowering women: land and property rights in Latin America. Pittsburgh: University of Pittsburgh Press, 2001.

DEERE, C. D.; León, M. Who owns the land? Gender and land-titling programmes in Latin America. In: Journal of Agrarian Change, v. 1, n. 3, 2001, p. 440-467.

DEERE, C. D.; León, M. Derechos de propiedad, herencia de la esposas e igualdad de género: aspectos comparativos entre Brasil e Hispanoamérica. In: Estudos Feministas (Florianópolis, Brasil), v. 9, n. 2, 2001, p. 433-459.

DEERE, C. D.; León, M. Liberalism and married women's property rights: continuity and change in nineteenth century Latin America. Paper prepared for presentation at the Latin American Studies Association International Congress, Dallas, Texas, March, 2003.

DE LA CADENA, M. Women are more Indian: ethnicity and gender in a community near Cuzco. In: Larson, B.; Harris, O. (Eds). Ethnicity, markets, and migration in the Andes: at the crossroads of history and anthropology. Durham, NC: Duke University Press, 1995, p. 329-348.

DE JANVRY, A.; Platteau, J.-P.; Gordillo, G.; Sadoulet, E. Access to land and land policy reforms. In: de Janvry, A.; Platteau, J.-P.; Gordillo, G.; Sadoulet, E. (Eds). Access to land, rural poverty, and public action. Oxford: Oxford University Press, 2001, p. 1-26.

DE JANVRY, A.; Sadoulet, E.;Wolford, W. The changing role of the state in Latin American land reforms. In: de Janvry, A.; Platteau, J.-P.; Gordillo, G.; Sadoulet, E. (Eds). Access to land, rural poverty, and public action. Oxford: Oxford University Press, 2001, p. 279-303.

ESPARZA, R.; SUÁREZ, B.; BONFIL, P. Las mujeres campesinas ante la reforma 
al Artículo 26 de la Constitución. México City: GIMTRAP, 1996.

ESTUDILlO, J.; Quisumbing, A. R.; Otsuka, K. Gender differences in land inheritance, schooling and lifetime income: evidence from the rural Philippines. In: Journal of Development Studies, v. 37, n. 4, 2001, p. 23-48.

FAO (Food and Agriculture Organization). Report on the 1990 World Census of Agriculture: International comparison and primary results by country (19861995). Rome: FAO, 1997.

Fundación Arias; Fundación Tierra Viva. La mujer y el acceso a la tierra en Guatemala. San José: Fundación Arias and Tierra Viva, 1993.

GALÁN, B. Aspectos jurídicos en el acceso de la mujer rural a la tierra en Cuba, Honduras, Nicaragua y República Dominicana. Consultancy Report. Rome: FAO, 1998.

GONZÁLES M., M. de la S. Familias campesinas mexicanas en el Siglo XX. Unpublished doctoral dissertation. Madrid: Universidad Complutense de Madrid, 1992.

IFAD (International Fund for Agricultural Development). Rural poverty report 2001. The challenge of ending rural poverty. Rome: IFAD, 2001.

INE (Instituto Nacional de Estadísticas). VI Censo Nacional Agropecuario 1997 Total Nacional. Santiago: INE, 1998.

INEI (Instituto Nacional de Estadística e Informática). Tercer censo nacional agropecuario. Peru: Perfil agropecuario, avance de resultados. Lima: Dirección Técnica de Censos y Encuestas, 1995.

LARA FLORES, S. M. (Editor). El rostro femenino del mercado de trabajo rural en América Latina. Caracas: UNRISD and Ed Nueva Sociedad, 1995.

LASTARRIA-CORNHIEL, S. Impact of privatization on gender and property rights in Africa. In: World Development, v. 25, n. 8, 1997, p. 1317-1334.

LEÓN, M.; PRIETO, P.; SALAZAR, M.C. Acceso de la mujer a la tierra en América Latina: Panorama general y estudios de caso de Honduras y Colombia. In: FAO 
(Editor). Mujeres campesinas en América Latina: Desarollo rural, migración, tierra y legislación. Santiago: FAO, 1987, p. 3-80.

LEWIS, J. Agrarian change and privatization of ejido land in Northern Mexico. In: Journal of Agrarian Change, v. 2, n. 3, 2002, p. 401-419.

MINISTERIO DE AGRICULTURA. Indicadores de Gênero en el sector agropecuario del Perú (con base en los resultados del tercer CENAGRO). Lima: Ministerio de Agricultura, 1998.

NAVARRO, W.; VALLEJO, A.; Villaverde, X. Tierra para la vida. Quito: Fondo Ecuatoriano Populorum Progresso, 1996.

NAZARRI, M. Widows as obstacles to business: British objections to Brazilian marriage and inheritance laws. In: Comparative Study of Society and History, $\mathrm{V}$. 37 , n. 4, 1995, p. 781-802.

Procuraduría Agraria. Los tratos agrarios en ejidos certificados. Mexico City: Procuraduría Agraria, 1998.

QUISUMBING, A.R. Women in agricultural systems. In: STROMQUIST, N. (Editor). Women in the Third World: an encyclopedia of contemporary issues. New York: Garland, 1998, p. 261-272.

QUISUMBING, A.; OTSUKA, K. Land inheritance and schooling in matrilineal societies: evidence from Sumatra. In: World Development, v. 29, n. 12, 2001, p. 2093-2110.

RENZI, M.R.; AGURTO, S. La esperanza tiene nombre de mujer. Managua: FIDEG, 1997.

REPÚBLICA DE GUATEMALA. Tercer censo agropecuario 1979. Guatemala City: Dirección General de Estadística, 1985.

REPÚBLICA DE PERÚ. Ley general de comunidades campesinas, ley no. 24656 de 13/4/87. Lima: Diario 'El Peruano',1987.

REPÚBLICA DOMINICANA. Quinto censo nacional agropecuario1960. Santo Domingo: Oficina Nacional de Estadística, 1966. 
Sociologias, Porto Alegre, ano 5, no 10, jul/dez 2003, p. 100-153

REPÚBLICA DE PARAGUAY. Censo agropecuario nacional 1991. Asunción: Ministerio de Agricultura y Ganadería, 1993. (electronic copy)

ROBLES, B. H.; Artís, G.; Salazar, J.; Muñoz, L. ...y ando yo también en el campo! Presencia de la mujer en el agro mexicano. México City: Procuraduría Agraria, 2000.

ROCHA, S. Efectos comparativos de la titulación a la pareja y la titulación individual en las mujeres y los hombres del sector reformado. Consultancy report, Project IDF 28275, Unidad de la Mujer Campesina, Dirección General de Reforma Agraria, Ministerio de Agricultura, Ganadería y Forestal, Managua, December, 1998.

SILVERBLATT, I. Andean women under Spanish rule. In: Eienne, M.; Leacock, E. (Eds). Women and colonization. New York: Praeger, 1980, p. 149-185.

SOCOLOW, S. M. The women of colonial Latin America. Cambridge: Cambridge University Press, 2000.

UN (United Nations). Convention on the elimination of all forms of discrimination against women (1980). New York: United Nations; reprinted by the Human Rights Program, Department of Secretary of State, Minister of Supply and Services, Ottawa, Canada, 1982.

UNDP (United Nations Development Programme). Human development report 1997. New York: UNDP, 1997.

VALDÉS, T.; Gomáriz, E. Mujeres latinoamericanas en cifras: Tomo comparativo. Santiago, Spain: FLACSO and Instituto de la Mujer, 1995.

VALENZUELA, A.; Robles, H. Presencia de la mujer en el campo mexicano. In: Estudios Agrarios: Revista de la Procuraduría Agraria, n. 5, 1996, p. 31-63.

VARGAS, V.; Wieringa, S.; Lyclama, G. Introduction. In: Vargas, V.; Wieringa, S.; Lyclama, G. (Eds). El triángulo del empoderamiento. Bogotá: Tercer Mundo, 1996, p. 1-53.

WOORTMAN, E. Herdeiros, parentes e compadres. São Paulo/Brasília: Hucitec/ Ed. UnB, 1995. 
WORLD BANK. World development report 2000-2001: attacking poverty. New York: Oxford University Press, 2000.

WORLD BANK. Engendering development through gender equality in rights, resources and voice. New York: Oxford University Press, 2001.

\section{Resumo}

A diferença de gênero em relação à propriedade fundiária, na América Latina, é significativa. São poucos os países nos quais as mulheres constituem sequer um quarto dos proprietários. A desigualdade de gênero na posse de terras é relacionada à preferência masculina no momento da herança, ao privilégio masculino no casamento, ao viés masculino em programas comunitários e estatais de distribuição de terras, bem como ao viés de gênero no mercado fundiário, sendo que as mulheres têm menor probabilidade do que os homens de serem compradoras bem sucedidas. Mas também existem diferenças importantes por gênero na forma pela qual são adquiridas terras. A herança é o principal meio pelo qual a maioria das mulheres se torna proprietária, enquanto que os homens têm muito maior probabilidade do que as mulheres de adquirirem terras através da sua distribuição por comunidades ou pelo Estado, e por meio do mercado. São destacados os fatores que contribuem para uma tendência no sentido de maior igualdade de gênero na herança de terras e em programas públicos recentes.

Palavras-chave: direitos fundiários, gênero, propriedade fundiária, desigualdade, herança, América Latina. 